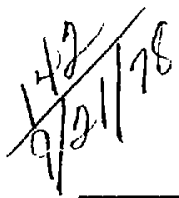

\title{
REVIEW OF THE NEUTRAL-BEAM CURRENT REQUIREMENTS FOR THE MIRROR FUSION TEST FACILITY (MFTF)
}

G.D. Porter, F.H. Coensgen, R.S. Devoto, A.W. Molvik,

J.F. Osher, J.W. Shearer, and K.I. Thomassen

August 4, 1978

Work performed under the auspices of the U.S. Department of

Energy by the UCLLL under contract number W-7405-ENG-48

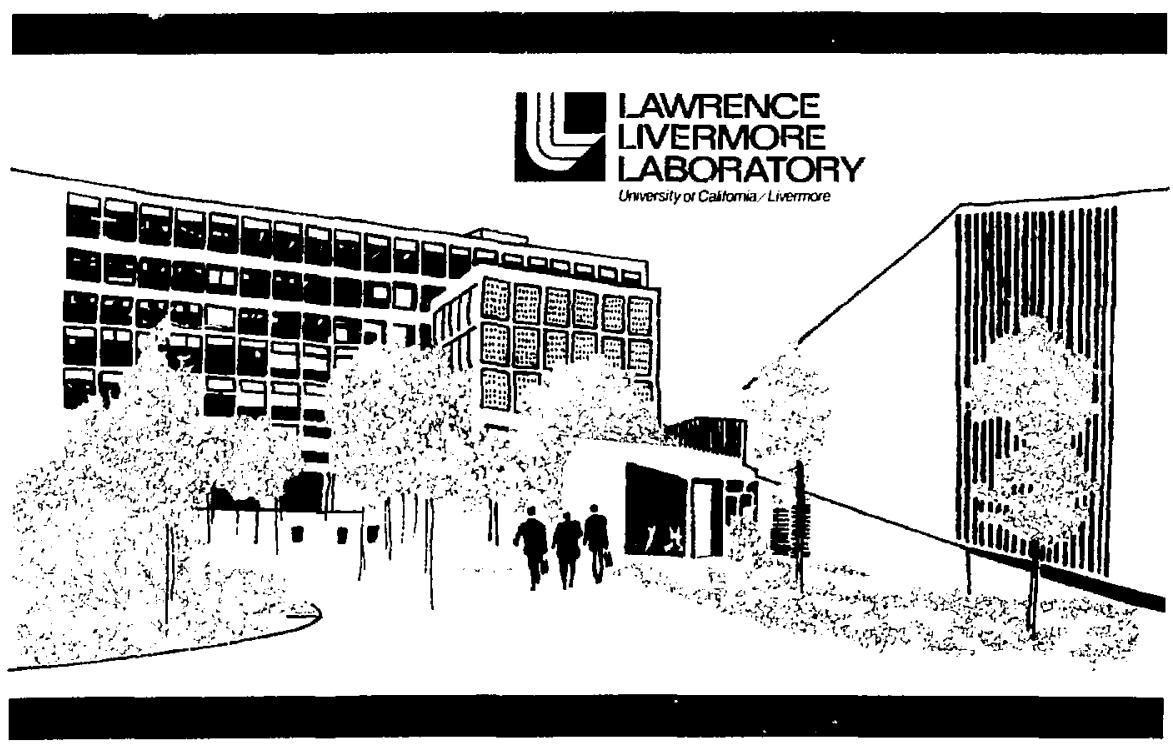




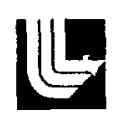

\title{
LAWRENCE IIIVERMORE I_ABORATORY
}

University of Callonia Livermore.California 94550

UCRL-52517

\section{REVIEW OF THE NEUTRAL-BEAM REQUIREMENTS FOR THE MIRROR FUSION TEST FACILITY (MFTF)}

\author{
G.D. Porter, F.H. Coensgen, R.S. Devoto, \\ A.A. Molvik, J.E. Osher, J.W. Shearer. \\ and K.I. Thomasien
}

MS. date: August 4, 1978

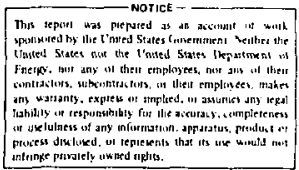




\section{CONTENTS}

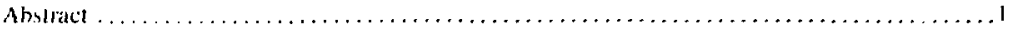

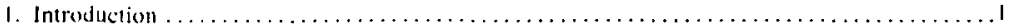

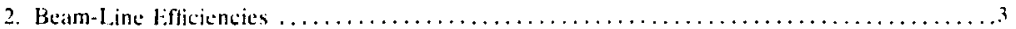

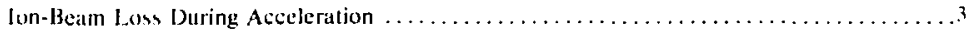

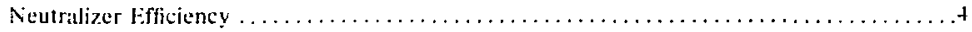

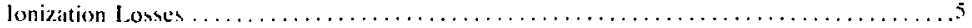

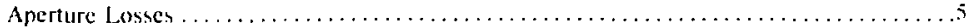

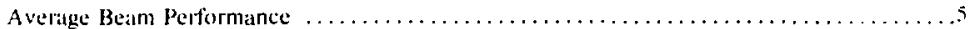

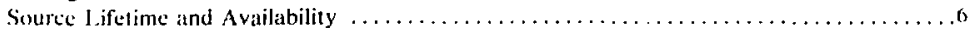

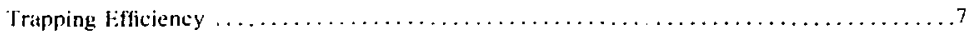

3. Sensitivity of the MFIF Current Requirements to Parametric Varintion ................"

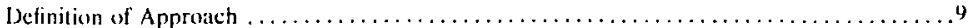

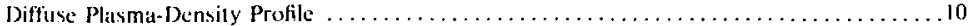

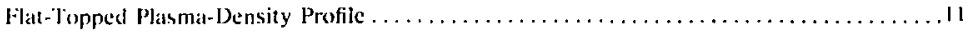

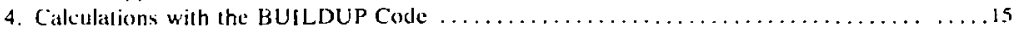

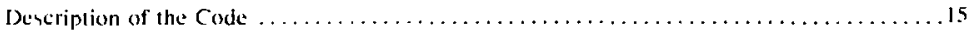

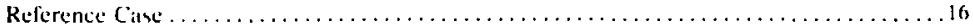

Fiffects of Changes in $n$

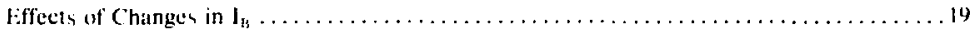

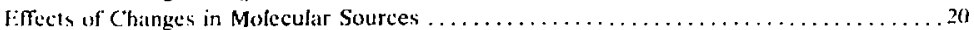

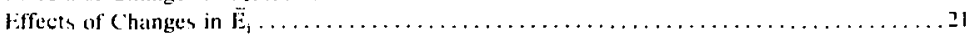

5. Neutral-Beam Current Requirements for Field-Reversal Experiments $\ldots \ldots \ldots \ldots \ldots \ldots \ldots 2$

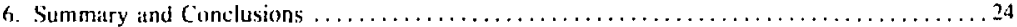

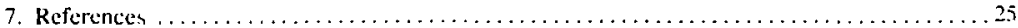




\title{
Review of the Neutral-Beam Current Requirements for the Mirror Fusion Test Facility (MFTF)
}

\begin{abstract}
Oul study of the neutral-bean current requirements for the Mirror Fusion Test Facility (MFTF) includes an antalysis of the expected operating parameters of the neutral. beam sources based on recent tests conducted at the Lawrence Berkeley Laboratory (1.BL. We find that the LBL. sourees will produce a neutral-beam module with an output current of $51 \mathrm{~A}$ and an average beam energy of $50 \mathrm{keV}$. To meet the MFTF goal of a plasmat having an average ion energy of $50 \mathrm{keV}$, this heam energy must be increased. Modification of the sourees to increatse the energy will reduce the output current.

The techniques used to evaluate the beam-current requirements for MFTF are simikar to those in previous studies but incorporate some improvements. In particular. we have enlarged the radial code BUILDUP to allow for a smaller radial grid and to improve the numerical accuracy: we have also improved the model of the atomic physics processes and the particle-equilibriun calculations. Also, a model of plasma containment that conserves energy as well as particles but does not include any effect of the expected drifteyclosem loss-cone (DCLC) turbulence has been incorporated into the previous stulies. We show that the DCLC turbulence increases the average ion energy and decreates the particle confinement time. Becaluse these effects cancel to first order. ihe beam-current requirements alre independent of the turbulence. We find that 24 of the present I. BI source modules would sustain a plasmat with an average beta of 0.46 . This figure is within $10 \%$; of the MFIl' goal and is within our calculational accuracies. We further show that the beam current requirements for the large-diameter plasma are consistent with those of exper. ments to study the builusup of a field-reversed plasmat.
\end{abstract}

\section{INTRODUCTION}

Becaluse the most expensive item in the Mirror Fusion Test Fucility (MFTF) is the set of $8(0-k \vee$ power supplies for the sustitining neutral he:ams. the number of power supplies reyuired to achicve the stated goals' has been al controversial topic...3 The issues involved, as reviewed in this report, fall into two categories:

- Whal is the expected beam-line output current from each source module (it furction of source operating characteristics and the alssociated beam-line efficiency; and

- How much neutral-bearn eurrent is required to achieve the MFIF goals.

We must answer questions from bolh cattegories before we ean determine the number of power supplies required for the MFTF
Seclion 2 addresses the firs calcgory: expected heam-line output current of each iource module. Previous studies preceded experience in operating sources similitr to those that will he used in the MFTF..':-1 Since those studies, persunnel at Lawrence Berkeley Laboratory (L BL, have tested 120-kV source noduses for Princeton's Tokanak' Fusion Test Reactor (TFTR) and reduced-atea. $80-k V$ modules for General Atomic Company's Doubles III, sourees similar in many ways to those that will be used on MFTF. By extrapolating the results of these tests, we obtain the expected performance of the MFTF sources. As the design of the fusion thamber system progresses, we can better estimate the transport efficiencies of the MFTF beam line and determine system atvailability and how it affects our ability to achieve 
the MFTF goals in a reasonable lime. Finilly, Sec, 2 also contains a re-estimate of the tapping elficiency expected in MFlF. This calculation differs from previous estinates ${ }^{\prime}$ in that here we treat the beatus as having a Gaussian density profile in both lamsverse dimensions. By disereet aiming of these focused beams, we can obtain large-alianeter plismats. Because in the determinattion of ldapping efficiency this treatment accounts for the portion of each beam that misses the plusma. The nomenclature used to discuss the beam-current requirements must be changed. Previously, beam-current requirements were stated in ierms of the current incidem on the plasma.. The beano-proble effects were aporoximated by sily ing that $20 \%$ of the heams misses the plisma." The be:m eurrents calculated hers, however. reter to the neutal current through the final apertuse of the MFIF beam line and are therefore citled the beam-lins sutput curests to distinguish them from the currents incident on the plasinat.

Sections 3, 4, and 5 contain our re-evaluation of the he:alm-cursent requirements for the MFTF sterence case. These estimates improve and wend previous work." Sections 3 and 4 treat ine rutrence eitse, where $\beta=0.5$ and the plasma radius is large enough lo permit stabilization of the Irifi-cyclouron toss-eone (DCLC) mole. In Sec 5. we consider the current requirements for an alternate reference caste: the buildup of a fieldreversed plasma.

An extension of the particle-equilibritum talextutions of Ref, 4 is presented in See. 3. The plasma confinement parameter and average ion energy are assumed to scale ats found in Ret. 5. We consider tho radial plasma profiles, diffuse and liat-topped, and show that although it is relatively easy to achieve at peak beta $\beta_{11}=0.5$ with a diffuse profilc, a very large current in necessary for an averitge bela $<\beta-=0.5$. For the flat-topped protite. we find that 24 source mudutes with the operating parameters of the present I.BI. models are stricient to achicve $<\beta$. 0.46 .

Recent result of calculations using the radial code BUILDUP are presented in Sec. 4. These citculations include an investigation of the sensitivity of the beam-cutrent requirements to variations in parameters such as the streaming-gats derisity. the plasna confinement parameter. and the mean ion energy of the plasmit. We show that the currents depend rather sensitively on the mean ion energy. This lact. which was not lully appreciated in the past. is important because achievenuent of a $\beta=0.5$ phusma is one of the MFIF goals. The code runs are all aimed at achieving at litt-topped plasina density profile. Results show that this prolile is relatively sensilive to beam aiming.

Calculations of the beitn-current requirements for a study of the buildup to field reversal are given in Sec. 5. Although these sludies were not inclided in the MFTF proposal. ' we feel they ale important enough to be considered as an alternate reference cise. The metheds outlined by Shearer and Condit' and Baldwin and Fowler are used to estimate the required current. We find that the current necessary to achicve a latge-diameler. $\ulcorner\beta-=0.5$ platsma is consistent with that reyuired for the study of the buildup of a fietd-reversed platsma. 


\section{BEAM-LINE EFFICIENCIES}

The specification for the sustaining neutralbeam power supplies calls for each supply to be capable of producing $88 \mathrm{~A}$ at $80 \mathrm{kV}$. Because of losses, only a fraction of this power is available as neutral-beam inpul to the plasma.

- The first lesss oecurs in the power supply for the gradient grid. This power supply is a passive, voltage-divider network that divides the aceil voltage down to that necessirly for the gradient grid. Fo present vollage satg at the gradtent grid. the divider network draws a significant current from the accel power supply. The present design requires an 8-A clrain in this network: henee, only 80 $A$ is available for ion-exllaction current.

- A portion of this remaining current (roughly $20 \%$ ) in lont hy processes oceurring in the grid itructures.

- Further lonses are incurred hecause of incomplete neutralization of the iun beam.

- Iosher accur in the hean line due to reionization by gits.

- I.usencuceur beciunc ol apertures designed to prevent gats straming from onlo the plasma.

- Cne efleclive loss occurs because the average performance of a group of injectors on the MFIF experiment is expected to be below that of a single injeclor on a lest stand.

- Another effective loss is it function of the finite lifeline of the source and the accompanying source availability.

- Finally, there is a loss due to the trapping efficiency of the plasmat.

Each of these los; mechanisns will now be considered in detitil.

\section{Ion-Beam Loss During Aeceleration}

lon beam san be lost two way s during acceleriition:

- By charge exchange on cold gass. and

- By generation of at nore divergent beam hatio by imperfect beam optics. Most of this divergent beam is expected to miss the grids: however. the beitm that does strike creates secondary elecIrons that can batckstream and increase the power supply drain.

The charge-exchange loss has been calculated by Fink and McDowell and more recently by Anderson." Anderson integrates the loss for analytic approximations to the charge-exchange cross section, with a beam energy increasing linearly and a gas pressure decreasing linearly with distitnce through the accelerating structure. He talculates an efficiency of $91 r^{\prime}$ all $80 \mathrm{keV}$ for the flow rates used on the LBL 120-keV source now heing tested. Following Anderion's model. we alculate losses of molecular ions by charge exchange and dissociation. Using a 5-keV step. we numerically integrate the cross section and the pressure from 0 to $80 \mathrm{keV}$. The D. gas density drops linearly over $1.5 \mathrm{~cm}$ from $1.3 \times 10^{1+}+10$ $0.65 \times 10^{11} \mathrm{~cm}{ }^{3}$. As shown in Tahle 1 . We find that the fraction of molecular ions lost is 0.169 and 0.157 for $D_{t}^{t}$ and $D_{3 .}^{*}$. respectively, and that the fraction of $D_{\text {; }}$ lost is only 0.092 . The loss rate seales linearly with the gats density.

'Iable 1. Estimates of' ion-beam losses during acceleration in the MFTF 80-keV source. The interaction is with [D, gas.

\begin{tabular}{|c|c|c|c|}
\hline \multirow[b]{2}{*}{ Charge exchunge of atemic species } & \multirow[t]{2}{*}{ Herterence } & \multicolumn{2}{|c|}{$\begin{array}{l}\text { Fraction of beum } \\
\text { that undergies } \\
\text { the isturastion }\end{array}$} \\
\hline & & & \\
\hline $\mathrm{D}_{1} \cdot\left(\mathrm{D}_{2}^{\prime \prime} \cdot \mathrm{D}_{1}^{\prime \prime}+\mathrm{D}_{z}\right.$ & A4.4 & 0.092 & \\
\hline c'harge enchange of mulectular species & & & \\
\hline $\begin{array}{l}\mathrm{D}:-\mathrm{D} ! \\
\text { Charhe enchange and disstesiution of molecular species }\end{array}$ & A4.3n & (1.16) & 0.164 \\
\hline $\left.\mathrm{J}_{;}+\mathrm{D}_{-}^{\prime} \rightarrow \mathrm{D}\right)_{1}+\mathrm{D}_{1}^{\prime}+2\left(\mathrm{D}_{1}^{\prime}+\mathrm{D}_{1}^{\prime}\right)$ & A.3.8 & 0.108 & \\
\hline$D_{+}, D_{2}^{+} \rightarrow D^{\prime \prime}, D_{2}+D_{*}^{\prime}$ & $\mathbf{A 3 . 2 2}$ & 0.104 & \\
\hline 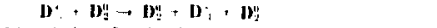 & $\mathbf{A 3 . 2 2}$ & 0.053 & 0.157 \\
\hline Dissicluatun of molecular species & & & \\
\hline$[\mathrm{D}: \rightarrow 2 \mathrm{2})$ & A.3.2 & 0.0 .31 & \\
\hline I) $v_{1}, b_{1}, D_{3}$ & A.3.20 & 0.018 & \\
\hline $13: \rightarrow\left[1:\right.$ i $\mathrm{In}^{\prime \prime}$ & $A, 3,20$ & 0.015 & 0.033 \\
\hline
\end{tabular}

"Page number in Kef. 12 from whicb cruss-stetional dalu weru ublained. 
The gas density used in these catculations is the best estimate" of the gath density used on the LBL $120-\mathrm{kV}$ lest stand. If this density could be reduced (and the neutralizer lengthened to mainlain efficient neutralization), the heam losses during acceleration would decrease.

Berkner'" measures beam losses of $20 \%$ in the L.BL. 120-keV source being developed for TFTR by delerinining the difference between the power to the calorimeter and the power supply drain. This number will be refined in the liuture by inore delatied mealsurements of whes beam is lost as well as by independent checks of the calorimeler accuraty. Berkner estimates that the $20 \%$ loss is mate up of lor; lost because of charge exchange and $10^{r} ;$ lost becaluse of a broader, non-Gatussian component to the beaus."

We une the lotal aceelemation loss of $20 \%$ and atssimle that it consists of the charge-exchange lumes listed in Table I plus the losses associated with a loroter hato to the beam. The halo is produced by three mechisnisms:

- Oplical defects (that we assume affect all species equally).

- Slower ions created by charge exchange (these are included in lable 1), and

- Slower ions resulting from the dissociation al molecular ions into lighter moleculiur or atomic ions (also included in Table 1 ).

The last two meehanisms produce ions that cannot he priserly locused becaluse they have the wrong momentum: hence, they broaden the beam. For the present species mix of $60 \% \mathrm{D}_{1}, 30 \% \mathrm{D}$, and $10 \%$ 1):- we thus obtain the following loss breakdown:

$$
\begin{aligned}
& {[0.042(0.60)+0.17(0.30)+0.16(0.10)]} \\
& +[\delta(0.60)+(\delta+0.031)(0.30)+(\delta+0.033)(0.10)]= \\
& 0.20 .
\end{aligned}
$$

where $\delta$ is the fraction of the beam with optical defects. The first bracketed $1 \mathrm{erm}$ arises from charge-exchange losses, and the second term arises from the halo losses. This results in $\delta=0,065$, and losses due to halo effeets of $0.065,0.096$ and 0.098 for $D_{1}, D_{2}^{t}$, and $D_{i}^{i}$, respectively.

In summary, we have calculated charge exchange and dissociation during acceleration for each of three beam species. We subtracted these losses from the calorimetrically determined loss rate of 0.20 , and then allocated the difference of 0.065 equally among the species. This vilue for the loss caused by optical defects seems rcasonable. We assume that the measured $20 \%$ grid losses will also be true for the MFTF sources.

\section{Neutralizer Efficiency}

The netaratizer efficiency is dependent upon the molecular mix within the souree plasma. Molecukar jons extracted ats ejther D, or D; will be dissociated in the neutralizer and will appear as atloms with encrgies corresponding to one-half and onethird ol" the extaction voltage." Since the chargeexchange crosis section is energy dependent, the neutralizer etficiency and averatge hean energy are dependint on the molectalar mix. We assume here that the extraction vollage for $M F I F$ is $80 \mathrm{kV}$. The mettralization fraction for $80-\mathrm{keV}$. 40-keV. and $27-\mathrm{keV}$ deuterium betams on D, gats is given in Rel. 12 as 0.625 . 0.82 , and 0.85 , respectively. However, because the neutralizer length required 10 athieve equilibrium in the $8(0-\mathrm{keV}$ eomponent is excessively long, we degrade the neutralization fraction $100.625 \times 0.95=0.59$. If $f_{1}$ is the fraction of the ion current extracted as $D_{i}$. and $f_{3}$ is the fraction extracted as $D_{3}$, the total neutral-beam current (in equivalent amperes) and power emerging from the neutralizer per ampere of extracted current is given approximately by

$$
\begin{aligned}
i^{\prime \prime} & =0.59 f_{1}+2(0.82)\left(1-f_{f}-f_{3}\right)+3(0.85)\left(f_{3}\right) \\
p^{\prime \prime}\left(\frac{W}{A}\right) & =(8 \times 101)\left[(0.59) f_{1}+(1 / 2)(2)(0.82)\right. \\
& \left.\times\left(1-f_{1}-f_{3}\right)+1 / 3(3)(0.85) f_{3}\right]
\end{aligned}
$$

The average energy in the neutral beam is given by

$$
\bar{E}_{11} \frac{p^{\prime \prime}}{i^{n}}
$$

The neutral current and averitge bean energy as determined from Eqs. (1) and (2) are plotted in Figs. I and 2. If the molecular mix for the MFTF $80-\mathrm{keV}$ sourees is the same as that measured in the $2 \times 11 B 20-\mathrm{keV}$ sources $\left(f_{1}=0.72 . f_{: 3}=0.02 \%\right.$. we would expect $0.93 \mathrm{~A}$ of neutral current per ampere extracted. The average energy in this case is about $56 \mathrm{keV}$.

The most recent tests on the TFTR and Doublet III sources at I.BL indicate a molecular mix of $f_{1}=0.6$ and $f_{3}=0.1$. For these sources, $i^{\prime \prime}=1.10$ and $\vec{E}_{B}=50 \mathrm{keV}$. This beam energy is inadequate to achicve the MFTF goal of an iverage ion energy of $50 \mathrm{keV}$. Sources developed at Oak Ridge National Laboratory (ORNL) improve the molecular mix by containing the source plasma with an array of magnetic multipoles placed around the arc chamber (the so-called MacKenzic bucket). These sources have achieved a moleculur mix of $f_{1}=0.85$ and $f_{i 3}=0.07$; hescec, $i^{0}=0.79$ and $\overline{\mathrm{E}}_{13}=64 \mathrm{keV}$. Current requirements for both of the LBL and ORNL sourees are considered in Sec. 3. 


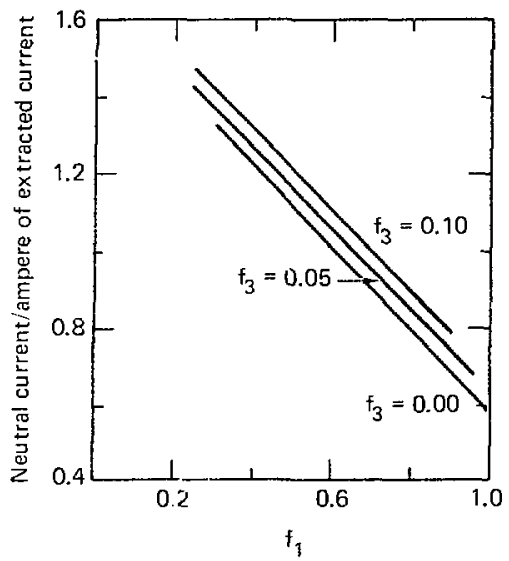

Fig. 1 The expected neutral current as a function of the mulecular mix of the surce. The neutral curront is normalized to the extracket surremt. The fraction of the buam extracted as

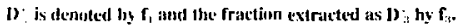

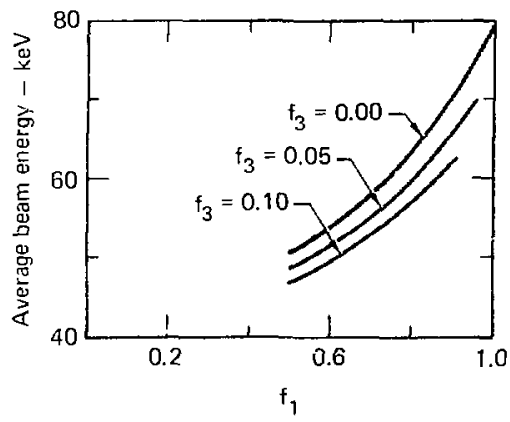

Fïg. 2 The average huan enurgy as a function of the molecular mix or the suarce. The nomencluture is the same as in Fig, $l$.

\section{Ionization Losses}

Another heam-loss meehanism in the beam line is the reionization of the neutral beam by gas between the neutralizer and the plasma. The strity matselic field sweeps these reionized particles from the beim. The transmission efficiency of the neutral heim is given by

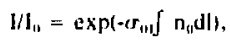

where $\sigma_{i 1}$ is the cross section for ionization of $D_{f}^{\prime \prime}$ by devterium gas and $n_{\text {o }}$ is the density of the gits molecules.

The beam-line conriguration used in the MFIF proposil' provided a transmission coefficient of $l / t_{\mathrm{t}}=0.81$. Design modifications and value engineering 10 increase the pumping area have increased this to $1 / I_{11}=0.89$. Because this loss has at very weak dependence oul energy in the 20 to 80-keV mange, we atsume for simplicity that the loss is $11 \%$ for all energy components. We are continuing to optimize the pump and aperture designs.

\section{Aperture Losses}

Further beam losses are expected on the apenures used to restrict gas flow from the neutralbeam tanks into the platsma. In the MFTF proposal ${ }^{1}$ a duct was used for this purnose. However. a loss of beam and increased cold-gas flow were found with the closely fitted duct associated with the beam line designed for the Princeton Large Torus (PI.T, by ORNL. Stewart ${ }^{1 . s}$ fitted the PLT results with a model of thermal gas reflux and has applied his analysis to the MFIF duet: he found that with the same reflux coefficient as in PLT, the MFTF beams were blocked after $0.3 \mathrm{~s}$. Therefore. the ducts have been replaced with apertures, and the pumping speed hats been increased to reduce gas flow to the plasma.

To estimate the loss of toilnt on the apertures. we require that the power loiding on the aperture be below $1 \mathrm{~kW} / \mathrm{cmi}^{2}$. We have anilyzed neutralbeam power profiles by means of the PWRDN cude't and find that $97 r^{\circ}$ of the heam will be transmitted by these apertures.

\section{Averige Beam Performance}

For two reasons, we expect that the average performance of at group of injectors on a continement experiment witl he beloss that of as single injector on a test stand:

- The experiment has a different environment (e.g. . a high magnetic field) that the test stiud.

- The atlention paid to an individual source and to the beam diagnostics mat he less complete and aceurate on an experiment than on at test stand: also, the reliable operating ieyel will be lower than the peak level achieved on a test stand.

Recent 2 XIlB performance is instructive. Through numerous improvements in operation, all 12 sources routinely operate at $18 \mathrm{kLV}$, injecting a total current of up to $530 \mathrm{~A}$ of atoms. This is about $90 \%$ of the LBL test-stand data abtained 
for the same energy. correcting for the different size of the ealorimeter. In addition. the operating voltage is 10$)^{\prime}$ low, resulting in a current about $15 \%$ below the design level. Therefore. the average operating current level of a 2 XIIB souree is athout $(0.9)(0.85)=0.77$ of peak test performance.

For MFTF, we are planning to improve on the $2 \times 11 B$ pertiormance:

- We are designing an improved magnetic shield based on the design for the Tandem Mirror fixperiment ( $\mathrm{TMX}$ ) (note that the MFTF field at the surce is $0.08 \mathrm{~T}$ rather than the $0.03 \mathrm{~J}$ on TMX).

- The computer control system will provide more anifi rm. attentive operation.

- We are working un obtaining adequate infermation at ith lewer diagnostics.

- 1.B1. in developing lower-current-density sulres that promise higher reliability. although this nates it hader to find room to inject sufficient curent into MFTF.

With ine improvemeats, we anticipate an averitge operating level of 0.9 of peatk test performance.

\section{Source Lifetime and Availability}

Wa exped liament busnout a limil the jifetime of the MFIF sources. LBI. has achieved 7000 11.5-s-duation shols and $2 X 11 B$ has recently achisved 900n 0.01-s-duration shots. On 2XIIB. source conditioning typically takes 1000 to 2000 shots: anosher 1000 shots are required for calorimetry. For MFTF, we estimate 1900 shots 10 condition and another 100 shoss to verily the aim and optimum operating parameters of a previously uperited soure. We expect computer monitoring and eonton to provide this more efficient aming and optimizattion. Conditioning can be done at 1-minute jntervala when plasmat experiments are not being run on the MFTF. Each source therefore requires 32 hours 10 condition, but many or all sources may be conditioned simultaneously at least to some fraction of full power and duration. Optimization and aiming will be done at a rate no faster than at 5 -minute intervals, and only beams hitting identified, distinct arcas of the calorimeter can be operated simultaneously: each source will require about 8 hours for optinization. We assume simjlas conditioning and optimizing times for the startup and sustaining beams, although this assumpfion may need modification ss we gain experience with sustaining beams.

After these 2000 preparatory shots, the source is ready to operate for data shots, with 5000 shots remaining befor: shutdown for maintenance. Each 16-hour daty allows 192 bhots at 5-minute intervals. At this rate. each source w ill last for 5.2 weehs of datat raking (shots taken during the 8-hour maintenance shift will shorten this period). This is much less than the approximate 13-week data period originally envisioned. However. with occissional days off for datal atualysis. the filaments might last the experimental period. We secognize that watrmuj) thots will be required at the begimning of each day and after interuptions in rumning. These shots will be make all 5-ninate intervits and may be comparable in number to the data shot. Typicilly then. we might expece 2500 datla shots and 2500 ararm-up sbots before shanging filaments.

The impact of this surece liletime on the availability of the NFIF newl mal-heim source and on the size of the maintenance shup depend or the stralegy we adopt for conditioning and maintaining the sustaining fand startupl neutral beams. In 2XIIB, we have used hatch processing: for MFI $\mathrm{M}$. this would mean maintaining and reconditioning itl reatral heams while MFTF in down for I month bet ween 2-month-duration dit i ruts. We find that filament lifetine is barely adequate to matke this a potential mode of operation. Furthermure, the workload on the maintenanee shop would he uneven. with peitk of 3 to 4 times the atverage worklout.

A more desirable operatilly secenatrio is that of continuous mainenance, where beam sources are removed from MFIF alt regular intervals (sacia as weckly), and a sleady workload is mainlained in the beam shop. We now analyze this ecenario for 1wo variations: for heame changed atl ratndom inlervals during the week and for all changing dont during the weekend.

- If we change sources at random times. the availatility of the heam y yem in ten by

$\epsilon=1+\left|\frac{\kappa R_{n}}{R_{c}}\right|^{1}$.

where $\alpha=$ conditioning/datla shots $\ldots 2000 / 2500-0.8$. and where $R_{\text {, }}$ and $R_{\text {, are the repetition rates for }}$ operation and conditioning. respectively. For $\mathbf{R}_{\mathrm{t}}=0.2$ min ' and $\mathbf{R}_{4} . \quad 1.0 \mathrm{~min}$ '. We ohtain $\epsilon=0.86$.

- By changing beams only on weekends, the conditioning can be neatly completed and optimization and aiming completed with an 8-hour shift on Saturday and on Sunday. Final conditioning would then be done during warm-up and data shots the following day. Although this stenario would yield an efficiency of unity, it involves optimistic assumptions. 
We recognise that se hedaled maintenance can increase the atralability of sources above the 0.86 calculated !or random-intervid maintenasace. However. the factors that prevent achieving unity itvalahility include unexpected failures of voureses, and the fact that sources may not be conditioned for to hours a day on weekends eisher hesatso of poncr-supply majnetiance or becaluse of mainicnance sithin the vault 1] at would probably require shutting heams down becalse of neutron hasads. However. becastese scheduled maintenance stould reduce down time by at least a factor of tho. We assunte a soleres avalbability of 0.153 bather than 0.86 .

We cith nute estinate the overall beam-line clficiensy by combining the transmission cousficient for eatch of the losuen fo review. the loss mechanisnis and the estinated transmission coefficients are tabulited in Tahle?

[:able 2. Be:am-line transmissiun coeflicitrats.

\begin{tabular}{|c|c|}
\hline I.cos machathinen & Trensmission conflerient \\
\hline- & - \\
\hline ucculeretion lossess & U, HU) \\
\hline lias reisutizatísr & $0.8 \times$ \\
\hline iproturn Jusnes & 0,97 \\
\hline Wreritge lation performatice & 0.9川 \\
\hline Selurce ascilabjlity & 0.93 \\
\hline Itital: & $0.5 B$ \\
\hline
\end{tabular}

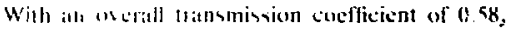
the expected hearm-line output current is $(6.38)(80) i "$

$52 \mathrm{i}^{\prime \prime}$ (A). wher: $\mathrm{i}$ " is determined in Sec. 2 . I he heilis-dina output eurrent for the presen: LBL. surces is $51 A$ soures with the Mackenzit hucket a impreve the molecular mix will have an sutput current of ،pproximatcly $37 \mathrm{~A}$.

\section{liapping Efficiency}

The techniques used he.t to calculate the heim ur oping efficiency follow very closely thuse int rodueed in Ref. 4. The main difference is that we account for the sratial dependence of the beam in the plithe perpendicular to its direction of propagetlion rather than just in the direclion of the magnetic axis (\%-axis). We alculate the trapping efficiency of a single bean aimed at the plasma nidplane (i.e.. at $z=0)$, with the boam center line aimed at an arhitlatry distance along the $;$-axis. The overall trappix, efficiency is then found by summing over all heams.
Let $J_{1}(y . z)$ be the output current density of the beam-line and n(x-y.z) be the densily of the plasma. The trapping efficionct is given hy

$$
\begin{aligned}
& y_{1}=1-\frac{1}{I_{13}} \int_{-x}^{x} d y d z J_{14}(x, s)<p \\
& \left.\mid-\frac{a r}{v} \int n(x)+1\right) d x \mid \cdot 13 x
\end{aligned}
$$

The neutral-heam sourees in $\mathrm{MI}[\mathrm{FF}$ will be focused: hence, the current density is hi-Gatussian:

$$
\begin{aligned}
& J_{n}(y, \mu)=\frac{1_{13}}{\pi L_{B} y_{u}} \exp \\
& \left|-\left(\frac{z}{z_{18}}\right)^{2}\left(\frac{3-y_{n}}{y_{k}}\right)^{2}\right|
\end{aligned}
$$

where $I_{n}$ is the total beam-line witpul eurrent aimed at $y_{\mathrm{H}}$. and $y_{\mathrm{B}}$. $t_{\mathrm{H}}$ are the ciale lengths of the s.o. .. 0.5 * 1.5 and beam focit length of $7 \mathrm{~m}$ : therefore.

$$
\begin{aligned}
& y_{11} \quad 700 \tan 1.5 \quad 18.3 \mathrm{~cm} . \\
& y_{11}=700 \tan 0.5 \quad 6.11 \mathrm{~cm} .
\end{aligned}
$$

We consider here only the case of a uniform cylindrical plasma: i.e..

$$
\begin{aligned}
& \left.n(x, y, z) \cdot n_{p}, \operatorname{re}\left(0, R_{,}\right), E(1) . I_{, .}\right) \\
& \text {- 0 vtheruse. }
\end{aligned}
$$

This model is a poo: representation or the diffuse profile considered in Sec. 3. nus it is a reas:mable approximation a.d the llat-topped plasnla-density protile.

With there assumplium. "e whtain the trap-

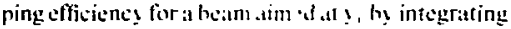
I.4. (3):

$$
\begin{aligned}
& \eta_{1}^{1} \operatorname{erf}\left(\frac{l_{-1}}{z_{13}}\right)
\end{aligned}
$$

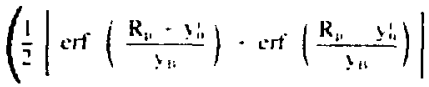

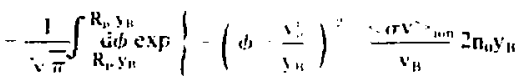

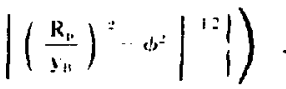

where $d=y / y_{1}$. 
We find the overalt rapping efficiency by summing over all heanis. 1 et fi, be the liriction of the eutil current that is aimed at position y!, Then for $\mathrm{N}$ heims.

$$
n_{i}^{N} \sum_{i}^{N} n_{i} \text {. }
$$

We assume here thall the lian plasmat elensits prolite is achieved hy $\mathbf{N}$ individual beam inmings

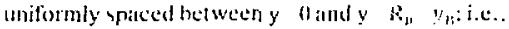

$$
y_{1}, \quad m \frac{K_{1}, y_{16}, m}{N}, 0,1 \ldots N \quad 1 .
$$

This aiming geometry is akelched in I.ig. 3 for the catse $N 4$.
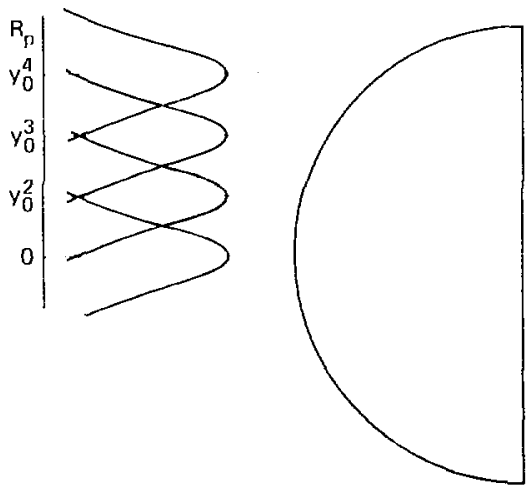

Fig. 3 Schematic of the beam pattern rectuired to achieve a large-dismeter plasma, showing pnints st, along the plasma radius $R_{p}$ at which the beam is timed.
The individual trapping efficiencies $\eta$; for

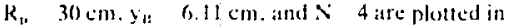

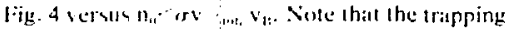
effeciency is disided hy erf $\left.l_{-1,} 7_{13}\right)$. In Ref. 4, the plisumat length $L_{L_{1}}$ is found to be $112 \mathrm{~cm}$. Then.

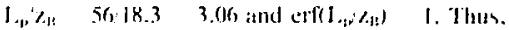
the finite length of the beats s is negligible fur beams focused al $z$ 1). Nots that in Ref. 4 it is assumed that the heiams are focured ia' the heatm domps rither than the plismit enturer. Hence, the beatn width $z_{p k}$ wat considerably lirger. Wh show in Sec. I that flat plasma density protiles recture more colrent almed at the edges than in the center: we

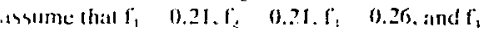

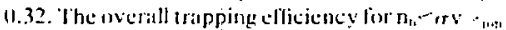

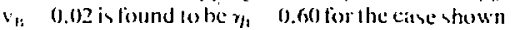
in Fig. 4. For atl casce comsidered in the following section, we assume that $y_{1:} 6.11 \mathrm{~cm}, \mathrm{~N} \quad 4$, and $\{1, ;:(1) .21,0.21,0.26,0.32)$.

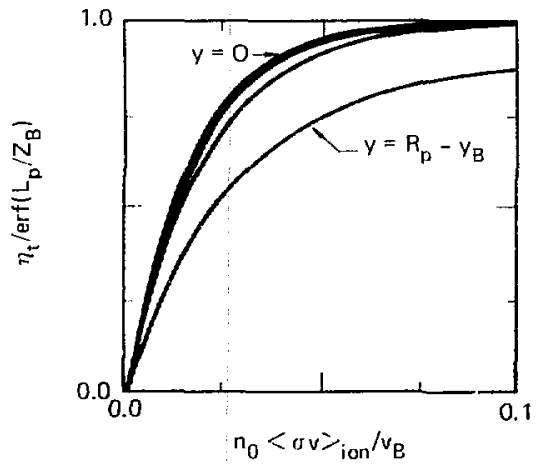

Fig. 4 The tean Irapping efliciency as a function of the plasma desnsily n, for a cylindrical plasma. The trapping, efficiency $\eta_{1}$ is calculated for beams ained at four points ergually spaced along the $y$-axis from $y=010 \mathrm{~g}-\mathrm{K}_{4}-\boldsymbol{y}_{16}$. Wls assume the plasma radius $K_{1}, 30 \mathrm{~cm}$ and the lewim width $y_{13}-6.1 \mathrm{~cm}$. 


\section{SENSITINY OF THE MFTF CURRENT REQLIREMIENTS TO PARAMETRIC VARIATION}

\section{Definition of Approach}

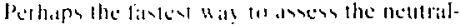

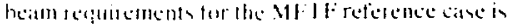

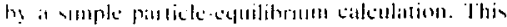

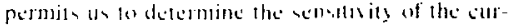

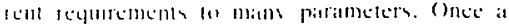

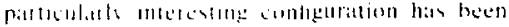

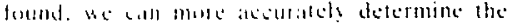

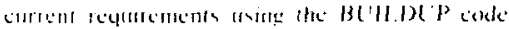

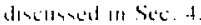

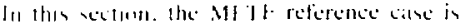

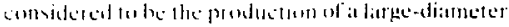

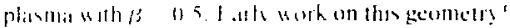

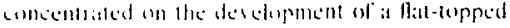

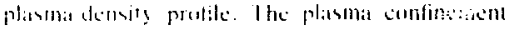

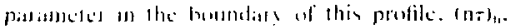

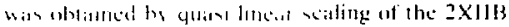

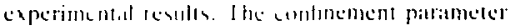

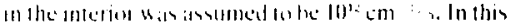

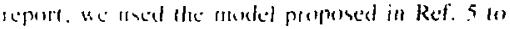

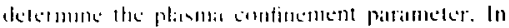
thas wat. buth particle and putser halance ale maintamed. Ir additum an the that-lopped prodile.

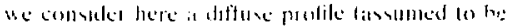
(iallsilitll)

li we adopt the notition of Rel. 4. the trapied cubent lequired to shratan planma-density describution mis.sing given bs

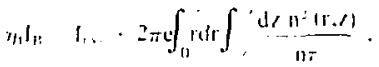

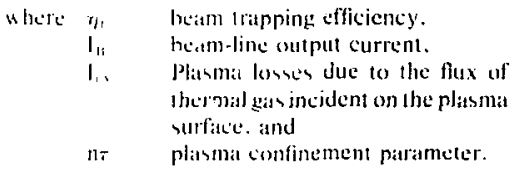

We utart wilh a general evaluation of Eq. (6). This is inlended to be useful only in alucidating the depenelence of the beam-line current 1. on patameters such as plasma $\beta$, average jon energy, and magnetic lick. Then. we determine the cursent requisenents for two secific plasma-density distributions: a Gatussian profile, and a nat-topped protile. To determine the general scaling of current, the plasma is modeled as a cylinder of length $L$. with a radial deasity profile given by $n_{11} f\left(r / R_{n}\right)$,

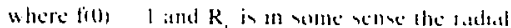

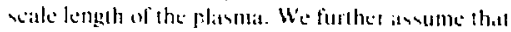
n; is independent af ratlum wh thit

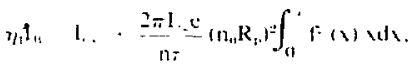

whic $x$ : $: R_{w}$

Stabilits of the planma agaiost the DCl.C mede reguire that the radial plasma-densts sate

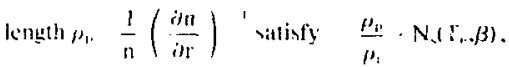

where $\mu_{1}$ is the lowal ion gyrorieditus and $N_{1}\left(T_{,}, \beta\right)$ in the nember of gyroriddi aleross the plasma. at determined in Ref, l. For this initial catculation. it is convenient to ignore finite- $\beta$ effects on the gyroladills: this assumption cannot be justified for some profiles and will be treated correclly later. Funhermore. it is convenient to assume $R_{1}$ - $p_{1,}$. Then.

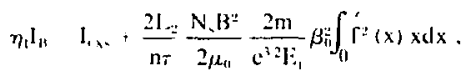

where $\beta_{11} \quad\left(n_{1,}, L_{1}, 2 / 2 \mu_{11}, \mu_{01}\right.$ is the permeability of free spice, $\hat{F}_{\text {, }}$ is the average ion energy. and $B$ is the vicuum magnetic field.

Nute that $2 \beta_{1} f_{1} f(x) x d x=\beta \%$. the a werag. plasma beta. For the diffuse profiles considered here, the value of $-\beta$ will be significantly less inan the peak vilue $\beta_{\text {at }}$.

We citl now w rite the genelalized current scaling equation

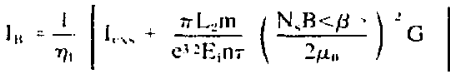

where $\mathrm{G}=<\beta>^{\prime} B_{11}$ is a profile-dependent geometry factor. Wo atssume that the colv gats surrounding the plasmat can be punped fitst enough to make the surface charge-exchange losses I... negligible. Bectuse this is not necessarily a valid assumption. the currents calculated here will be smaller than actually required. The BUILDUP code treals these losses properly. 
In See. 2. uce hilu that fill small values of

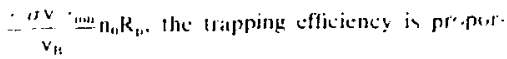
lionisl lo $n_{11} k_{1}:$ l.c...

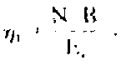

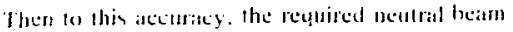
current acilles as

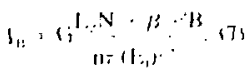

lhele ale several interesting points abut has penclal soilinge cyuation:

- There is unly in relativaly weak depemelence an $t_{1}$. This is importam since there is mols ancer. tailly in pedicling this paratuener. for example. fohter-l'lanck calculations wilh an ingection encegy of bel heV and an elecerom temperature of

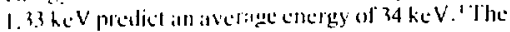

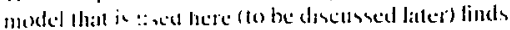
an averatge enelgy ol ankev. Sealing $2 \times 113$ resull a indiciales that the inn encerey conkl be as higin as 50 kel.' I his difterence mat be catlsed by lowaling

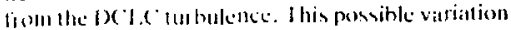
in the avelage ion concrgy alone callses an appiarenl $47^{\prime}$; uncertanty in the chergy and hence athout at

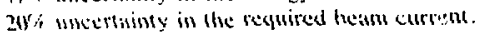

- The required heam entrent is detejmined hy the average heta together with a profiledependent geomelry factor. This means that a plasnat profile in which the average and peak hetas are nearly equal li.e.. a lat prolile) provides a more efficient ase of beam curlenl. This point will beconce more evident in conıaring the nat-topped and diffuse profiles considered later.

- Uncertainties in the paramelers L., $N_{s}$, and no are reflected linearly in uncerlaintics in the required beam current. The length used here is that determined by Staliard and Rensink (we routud the $68-\mathrm{cm}$ length found in Ref. 4 to $70 \mathrm{~cm}$ ). This length is dependent upon the electron temperalure in the sense that losses from plasmas with higher clectron temperatules are more nearly dominated by Coulomb collisions: hence, the plasmas are longer. However, this dependence is not included in this report.

- The value of $\mathrm{N}_{4}=13$ is as decrmined in the MFTF proposal' for an electron temperature of I keV. Again, the dependence of this parameter on electron temperature is not included in this report.

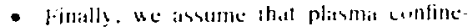

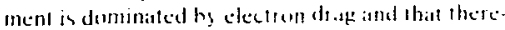
lise no seisles is propored in Rat. 5. The scilling lates are glven b?

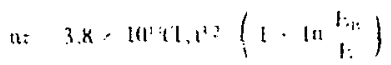
$(m:-4) \cdot(k)$

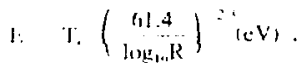

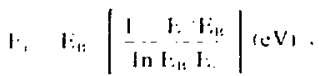

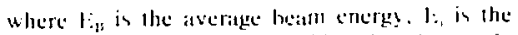
average plasma inn enerey, and $R$ is the mirren ratio

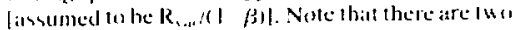
diflerences helween these equatsons and thone liound in Kef. 5: clectron temperatare riether than neatl eleclasn energy is lased as at variable. and the (oulumb hogarithm is 1.5 , rather than 20 .

\section{Diffuse Plasma-Iensity Profile}

The plasmas produced in the 2 XIIB experimenl lypicitly hase a cilfune (cisussian) radiat: profile. The density rofile is then fiaced by

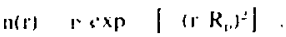

We lind the neutral-beam cartent required to surtain this prolile by inserting l:a - 111 into tiq. $(6)$ and integrating. I he plasmat radius $R_{1}$ is determined by the requirement that the DCICC mode he stable at the desired electron temperature. This stability requires that the atio of the focal plasmadensity seale length no the local ion gyroradius be greater than the number $V_{\text {w }}$ i.e.

$\frac{\rho_{n}}{\rho_{i}}=\frac{1}{\rho_{1}} \frac{1}{n}\left(\frac{\partial n}{i r}\right) \quad \Rightarrow N$

For a Giassian profile, $\rho_{10}=\mathrm{R}_{1}^{2} 2 \mathrm{r}$ : henee, the scale length is dependent on the radius. We assume here that the DCLC stability condition must be satisfied from the axis to the radius that contains balf the plasma; i.e., it nust be satisfied for $r\left(9.83 R_{p}\right.$. Furthermore. we assume that the local jon gyroratius can be deternined from the long, thin model;i.e. $f_{i}$ $=\left(\beta_{1} t_{\text {val }} /(1-\beta)^{\prime 2}\right.$. Inequality (12) then becomes

$\frac{\rho_{1}}{\rho_{1}}=\frac{R_{4}}{\left(\rho_{1}\right)_{1}} \frac{(1-\beta)^{12}}{1.66} \geqslant N_{N}$. 


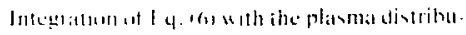

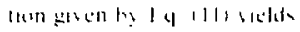

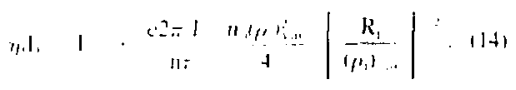

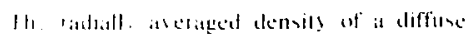

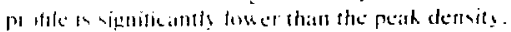

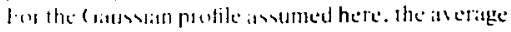

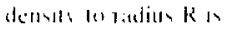

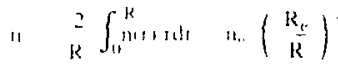

$$
\begin{aligned}
& |\sin ||R \cdot R,|) \mid
\end{aligned}
$$

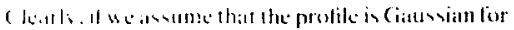

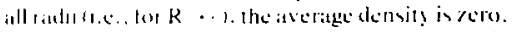
A mode tealsuk issumption is that the profile is frambiatl obe afproumalels one order of magmIuk.1 . . R $\backslash 2 k_{2}$. Ihen.

$$
\text { n } 11.4 .
$$

Iher, if a plis mat in firmed with at peat beta of $\beta$, -

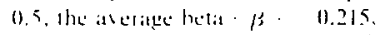

He cill Hes exprest fy. 114] in terms of the fs. hy molitg: that

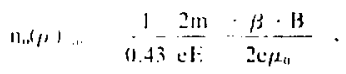

where $B$ is the vatum mongetic fiekd. Using this relationship together wath Feds. (8) and (13), we can write 1:4. 114) is

$$
\left.\gamma_{i} l_{1:} \quad 1, \ldots, 9.5,10\right)^{2,4} \frac{1-\beta-B N, j^{2}}{1, n \pi(1-\beta-1)} \text {, }
$$

Where 1. and are arelermined from leys. (10) and (8). respectively.

The required inapped eurrent, i.e., $\eta_{1} \mathrm{I}_{k}, \ldots$ I.... in plotted as a function of electron temperature in Fig. 5. The rapping efficiency found in Sec. 3 is reatly only applicable on nat profiles. However. beciuse the trapping efficiency for diffuse profiles would nut be expected to be larger than for a flat profile, $\eta_{1}=-0.67$ is expected for $\mathrm{T}_{4}=1 \mathrm{keV}$. Over 50 source modules would be required for $\langle\beta\rangle=0.5$. It is evident, then, that for the Gaussian profile. the $<\beta$, that is achievable with reasonable beim

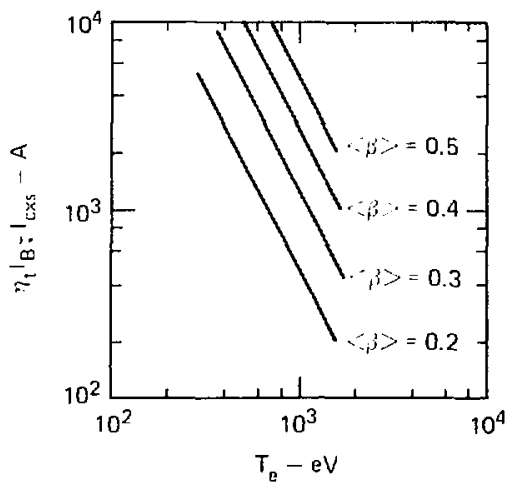

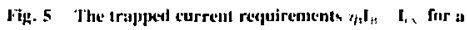
(iaussian plasma profile as a function of the electron temperature for four valust of acerage lecta $-\beta$.

currents is low. It is desirable to produce a profile that use the heams more effectively and fills the magnetic will more completely. Such a protile is the litt-top-profile considered next.

\section{Flat-T'opped Plasma-Density Profile}

The flit-lopped plasma-density profile utsed here is shown in Fig. 6. In the interior $\left(r-R_{k}-\right.$ $\lambda \rho, 2)$, the plasnat confinenent parameter is $\left(n-l_{1}\right.$ : the plasma confinement parameter is $(n t)_{1}$, in the boundary $\left.\left\{r \in \mid\left(R_{n}-\lambda p_{1} / 2\right) .\left(R_{1}+\lambda \rho_{1} / 2\right)\right]\right\}$.

Jnegration of E.q. (1) with this profile yiclds

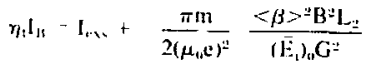

$$
\begin{aligned}
& \left|\frac{1}{\left(\mathrm{n}_{11}\right)}\left(\frac{\mathrm{R}_{1}}{\rho_{11}}-\frac{\lambda}{2} \frac{\rho_{1}}{2 \rho_{11}}\right)^{2}+\frac{2 \lambda}{3} \frac{\rho_{11}}{\rho_{11}}\left(\frac{\mathrm{R}_{\mathrm{r}}}{\rho_{01}}-\frac{\lambda}{4} \frac{\rho_{\mathrm{b}}}{\rho_{11}}\right)\right|
\end{aligned}
$$

where

$$
\begin{aligned}
& G=\frac{\ulcorner\beta>}{\beta_{11}}=
\end{aligned}
$$

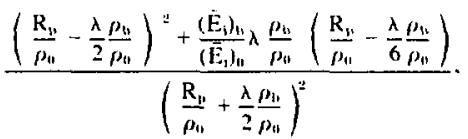

and where all units are in the MKS system except for the electron and ion energies, which are expressed in eV. The use of the substript b in Eq. (17) 


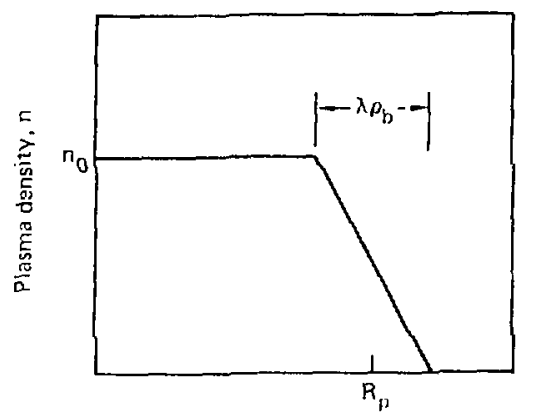

Plasma radius, $\mathbf{r}$

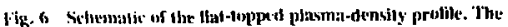

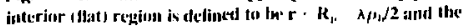

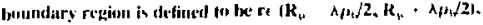

refers to the value of a pirimester in the bollndary: subscript o reliers to the interior, or that, pertion of the notile.

licuattion (17) is written with the assumption bat the plasma ratdius required for slabilization is determined by $R_{t} /\left(p_{10}\right)_{1: 11}$. linite- $\beta$ effects are less severe fir llat profiles than for the diffuse prodile. If the profile is truly flat, $\mu_{1}:\left(\frac{1 d n}{n d r}\right)^{\prime} \rightarrow x$ in the inlerior region, and the plasma is stable against the ICI.C mode. In fiset, the condition for stability. including finite- $\beta$ effects, is

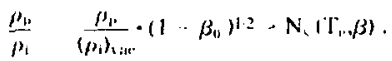

Then, if we atssume that the density decreases linearly with radius in the interior, the maximum permitted density change over radius $R_{p}$ is

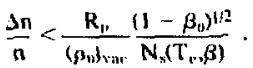

Finite- $\beta$ effects require that the "fiat" profile be more nearly flat. For example, if' we choose $N_{s}$ so that the plasma is stable with no stream $\left(N_{\mathrm{s}} \approx 50\right)$ and $R_{1} / \rho_{0} \approx 13$, then from Eq. (I9) it is evident that at $\beta_{k}=0.5$, the density decrease in the interior can he as much as $20 \%$. Since there will be radial mixing of the plasma over distances of at least an ion gyrodiameter, the plasma radius must be chosen to be at least several local ion gyrodiameters. In this report, we choose $R_{1} / \rho_{0}=13$.
It is Interesting to compare the trapped current caslculated using fy. \{ | f \} i with I, of with that determined uhing the BUII.t)UP code. We have done this for twa carses, the first thing the following parametric values: $\left(1 \sum_{1} l_{1} \quad\left(1 i_{1}\right)_{h} \quad 50\right) \mathrm{kc} V,(n-)_{n}-$

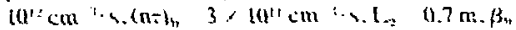
0.5. $\left.R_{12}\right)_{1}$ 1.3. and $\wedge \quad 4$.

We tand the reguired tripped current. using liq. (18). (o be 413 A comparted to the $570 \wedge$ determined using the BUII,DE: Perte. 'The second comparion was made with the same parameters except $\left(E_{1}\right)_{t}, \quad\left\langle E_{1}\right\}_{\mathrm{n}} \quad 30 \mathrm{keV}$. In this tave. the required 1rapped ectrent was fiund on be b88 $A$ using Fa. (IK) and gos A from the BLII.SUPP coule.

In both compiarisons. the BLIL.DUP code find an approximately $35 ;$ bigher lrapped curent. Inciuding the surfitce chatge-exchange losses feal-

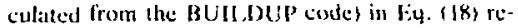
duces ine discrepanty 10 approximately 30$)^{*} \%$. This difference is attrithatahle lodifferences between the plasma-ciensily profile achieved with the BUII.DUP code and that assumed here. Since the density profite calculated by the BUIt.DUP' code is consisfent with the bean depusitinan rate, it is more realisiic. Ta account fur these sarrections, we increase the trapped current calculated by fy. (1R) ( with $I_{1}$. . 0) hy $3.5 \%$.

The salue of the platsma confinetnen parameler (nt) obtained from $\mathrm{Eq} .(\mathrm{x})$ is approximately a factor of two higher that that teed in the MFTF proposal.' Including enbanced seattering due to DCLC Iurbulense is expected to reduce the confinement. It is not cleat how to include this larbulence in a manjer that preserves both particte and power balatnce. One melloes, useful to atssess the effect, is to increase the coeflicient of the ion Coulomb scatlering time used in deriving F. 19). This has the effecl of increasing the particle loss rite and henee increasing the atverage jon energy. Both of these increases are expected from DCIC turbulence. We find that the required beam current is lie: ly (within $10 \%$ ) indeperitent of the Coulomb scattering coefficient. The efiect of reduced particle continentent is just balanced by the increase in the average jon energy. Il seems reasonable, then. to neglect the effect of DCLC turbulence and to use Eqs. (8) and (10) to deternine the particle confinement lime and average ion energy in hoth the interior region and the boundary. The values of the electron temperatures in these regions are thosen consistent with $R_{1} / \rho_{11}$ and $\lambda$. Thus, for $R_{1} / \rho_{10}=13$ and $\lambda=4$ we choose $\left(T_{1}\right)_{41}=1000 \mathrm{eV}$ and $\left(T_{1}\right)_{14}=200$ eV.

The $<\beta>$ that can be achieved is plotted in Fig. 7 as a function of the number of source modules 


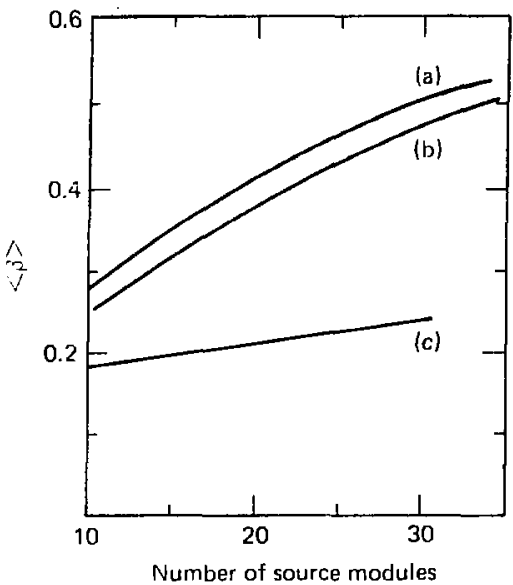

Fig. 7 The achitwable averagu plasma heta $\gamma \beta$, as a function of the numier of source moduls. Curves (a) and (b) are for the flal-topped prolite, with (a) being for the present I, BL, sources (F) $5(1 \mathrm{keV}$ ) and (b) heing for a future source with higher tram entray ( $F_{\text {.1 }}$ (A keV). Curve (c) is for a (jaussian plasnit-density profile and the presient L.BL, sourte.

(and power supplies) avajlable on MFTF. As previously discussed, the current calculated from E4. (18) is increased by $35 \%$ to calibratc it with the HUILDUP code results. We obtain the trapping tsficiency $\eta_{t}$ using the tectoniques outlined in Sec. 2 . andi use the beam-line output culr:nt per soulce module that is also determined in Sec. 2. We consider two source modules: the present I.BI. module and an anticipated module with better molecular mix itnd therefore higher beam energies. The corresponding curve for a diffuse profile ubtained with the present L.BL source molule is also included in Fig. 7. (The trapping efficiency is assumed to be $\eta_{\text {, }}$ $=0.67$ for this case.) With the L.B1. source, we find that the average ion encrey calculated from $\mathrm{Eq}$. ( 10 ) is about $35 \mathrm{kcV}$, while it is about $43 \mathrm{keV}$ for the "Tuture" source. The interior confinement parameter $(\mathrm{n} \tau)_{1}=2 \times 10^{2} \mathrm{cn}{ }^{\text {in }} \mathrm{s}$ for both sources. DCLC lurbulence expected to increase the average ion energy and to reduce the plasmal confinement, but the current requirements will remain approximalcly the same as shown in Fig. 7 .

The sensitivily of the current required to athieve $\angle \beta \Rightarrow=0.5$ to variations in parametric values is shown in Fig. 8. In Fig. 8(a), we show the sensitivity to the boundary parameters $\lambda$ and $\left(T_{0}\right)_{1,}$. and in Fig. 8(b) we show the sensitivity to the interior paramelers $\mathrm{R}_{1} / \rho_{1}$ and $\left(\mathrm{T}_{1}\right)_{1,}$. The reference catse of $\lambda=4 . R_{1} / \rho_{11}=13,\left(\mathrm{~T}_{1}\right)_{11}=1000 \mathrm{eV},\left(\mathrm{T}_{1}\right)_{15}=$ $200 \mathrm{eV}$ requires approximately $1430 \mathrm{~A}$, and the plasma confinement and average energy are $(n \tau)_{1}=$

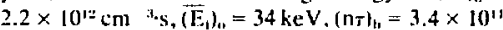
$\mathrm{cm} \cdot \mathrm{s}$. and $\left(\overline{\mathrm{E}}_{\mathrm{j}}\right)_{\mathrm{h}}=20 \mathrm{keV}$.

The current requirements san he significantly reduced by decreasing $\lambda$. even if there is a resultant decrease in $\left(T_{1} h_{h}\right.$. This arises because of an increatse in the value of $G=\left\langle\beta>/ \beta_{11}\right.$. However, the BUILDUP code results indicate that the beam aiming required to produce a fat profile in the interior will also produce a boundary region with $\lambda=4$.
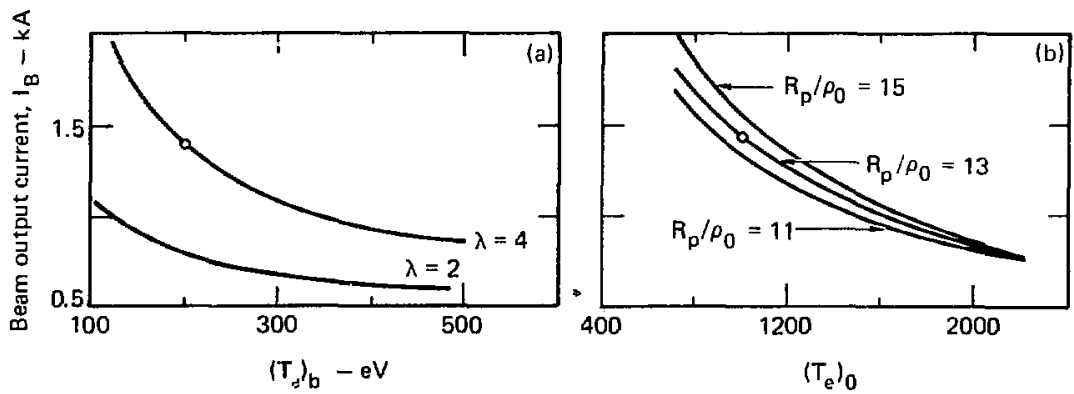

Fig. 8 The dependence of the beam-line output current $I_{13}$ on 1 he parasicters of a plasma with a flat-toppert density profile with an average beta $\langle\beta\rangle=0.5$. Dupendence upon the electron temperature und $\left(T_{i}\right)_{\text {, }}$ and the paramelers in the buundury is shoun in (a) und dependence on the ceniral-plasma parameters is shown in (b). Data points show valus for the NIFTF reference case. 
Hence, the use ol ate boundaty region is poobibls mol in independently adpustiable partanteter.

[1 the ridfus of the interene is reduced from

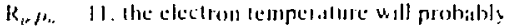

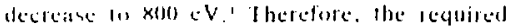

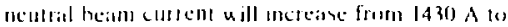
19fol A. and atteropting to matke at smadleo plasmis

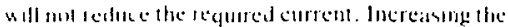

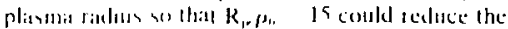

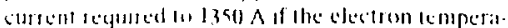

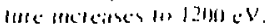

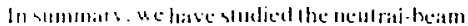

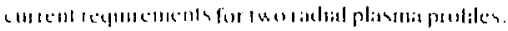

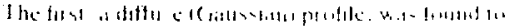

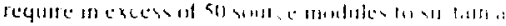

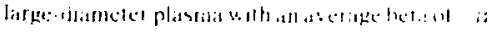

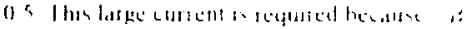

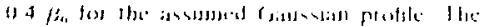

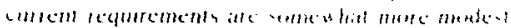

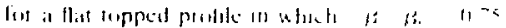

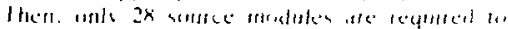

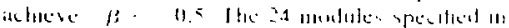

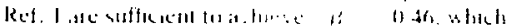

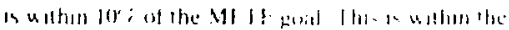

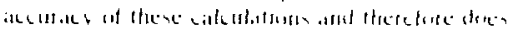

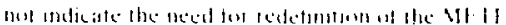
knish 


\section{CALCLATIONS WITH THE BLILDLP (OOHE}

\section{Inescription of the code}

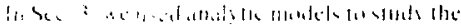

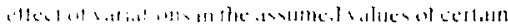

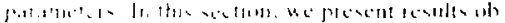

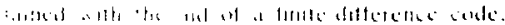

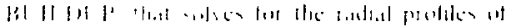

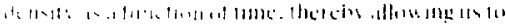

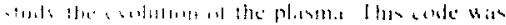

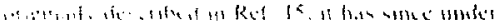

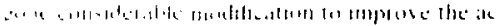

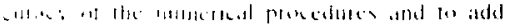

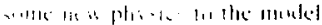

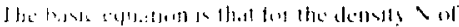

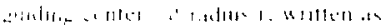

$$
\text { Vi1. }
$$

11

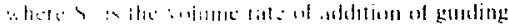

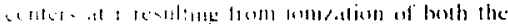

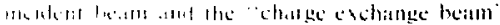

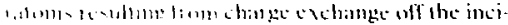

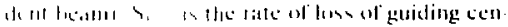

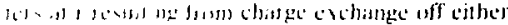

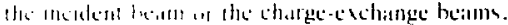

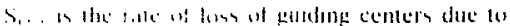

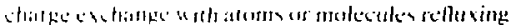
fum the statle and $S$, is the rate of lons of guiding

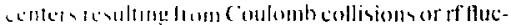

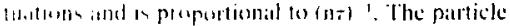

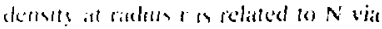

III. II $\frac{2}{\pi} \int$

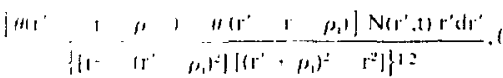

where ax $\quad 9,1$ is the Heatriside fonetion.

In compuling $S_{i s}$ and $S_{\text {ine. B }}$ BUll.DUP accoumts for the finite sarmor radius:i.c., the ahsorption of a heam atom adds to the guiding-center

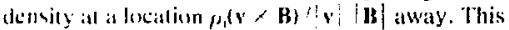
Importanl eflect is illustrated in Fig. 9. Ionization or chalge exchange at $t$ adds to $N$ at $B$; chatge exchange suhlracts from $N$ at $A$. Thus, in the orientalion of $y$ and $B$ shown in Fig. 9. charge exchange ofT Ihe bean causes a thet outward diffusion of guiding cenlers. This effect can be ased to advanlage in balincing the losses duc to surface erosion $S_{11}$, in I:y. (20). In the strong densily gradients at the edge of the plasma, lbe absorntion of beam aloms occurs

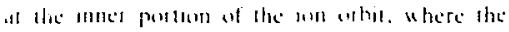

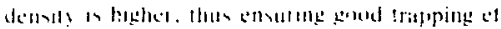

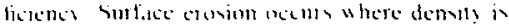

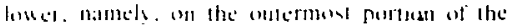

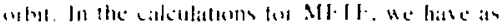

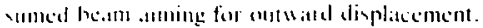

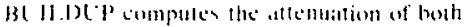

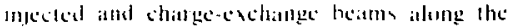
cotactane of the boum, Multiple generations of

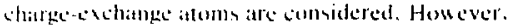

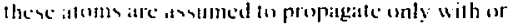
coumte to the injected heims. hereby neglecting angulita xaltering.

Ihree heams of twa different enelesics, six beams an total. alle allowed low in the corle. The plasmat. fikenise. is combidered ta consist of two

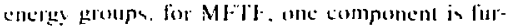
nishet by the stats-up beamm al an assumed mean ctuctes of 14 heV: the oher is the main sustaining heam at st) keV. No energy eqtations atce used in the cocle, int the (ni) valuc enmes from energy compideration discussed clsewhere in this repurt.

In cualuate the suface charge-sxchange lerm $S_{\text {It }}$. se muse know the denutices of the molecules and the reflex atums at the plasmat surface. We atsoume that plasmat ione lost by charge exchange reflux cither its aloms or as nolecules. In the present canc, hecause of high plasma tentrgy, charge-exchange particles penetrate the chamber surfitce and atomic reflux is probably negligible. To be conservative, we have taker the atomic reflux

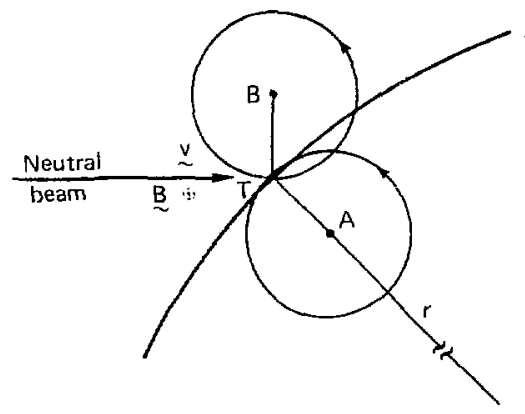

Fij. 9 Schematic of lewam trapping in plasma. Trapping at $T$ depwsits a guiding conter at B. Charge exchange at T noves a guiding cunler from $\boldsymbol{A}$ to $\mathbf{B}$. 


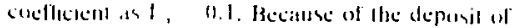
thanam wh the ualls, there is protatsly no

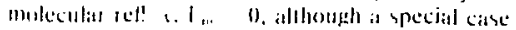

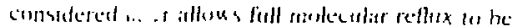

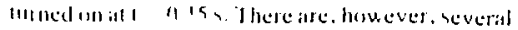

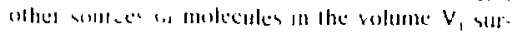

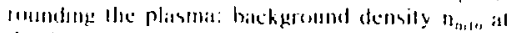
the imbialion at the experiment, sleitming gas down the neutral heam lines geven as equivalent

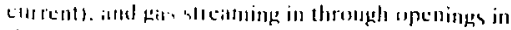
the manged regu bient areat $A_{1}$. from the volume

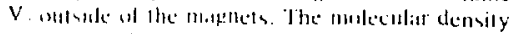

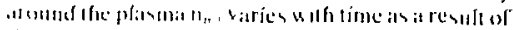

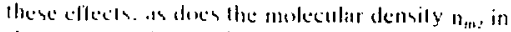

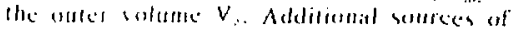

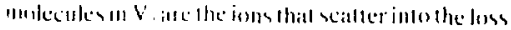

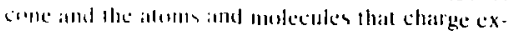
chathe sulle phandia surface and are suept onl hy

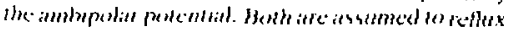

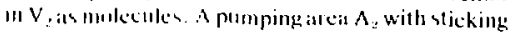

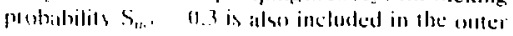
(a)lume.

Ihe lims term $S$. in compuled with a model molumg imo /

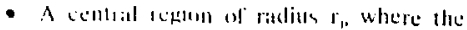

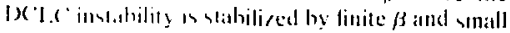
demolly graticht and where losses are viat classical processces: and

- A humalary liver of thickness or where the 1)('l. (' mole is suppresued by a watm. slreaming plasmbis. but at the expense of lowered $\mathrm{T}$, and redeced 10 . The Ihickness of the beundaly byer is net known a prieri. hut is obtatined as past ol" the

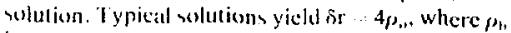
is hased on the vacuum fickl.

A typical BUILDUP cilculation for MFTF proceeds as follows: at $1=0$, the streaming-plasnat guns are durned on to provide at tatrget plastrat. ats atre the startup- and sustaining-beam modules. The code solves Eq. (20) logether with the appropriate expressions for the injection beams, the charge-exchange beams, reflux beams, and molecular and atomic densities in volumes $V_{1}$ and $V$., The target stream is lurned off at 5 ms (hut a stabiluzing strean must be left on in the boundary layer) and the sturtup beams are terminated at $10 \mathrm{~ms}$. The evolution of the plasma can be followed for the $0.5-\mathrm{s}$ duration of the experianent; steidly stitte is usuatly found after about $0.15 \mathrm{~s}$. We have run a reference case, corresponding to the parameters in Table 3 , and also several variations. The results are beseribed in the following discussions.

\section{Reference C'ase}

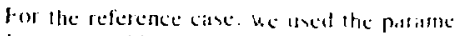

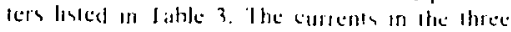

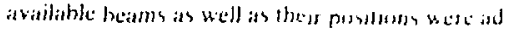

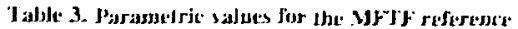
case: ${ }^{-1}$

$$
\text { parameter }
$$

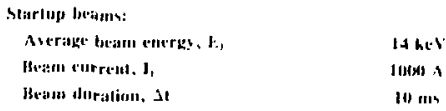
the foffowifng: a $\rightarrow$ ntomic, at :- molecular, and I and 2 refer to surfaces surrounding the plusma ancl butsidte the meagnets, respectively.)

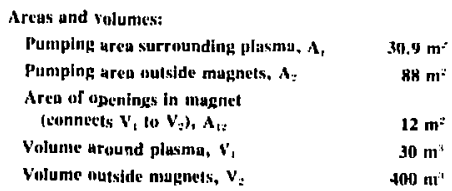

"From Ref. I5. 


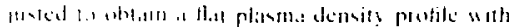
a 11 in 10 '

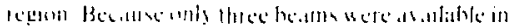

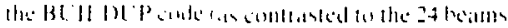

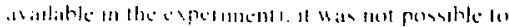

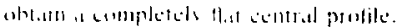

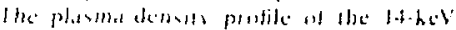

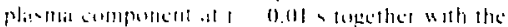

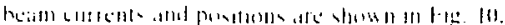

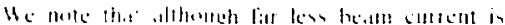

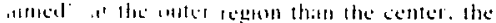

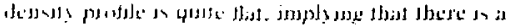

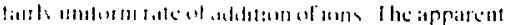

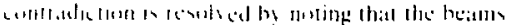

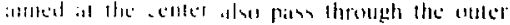

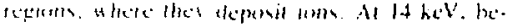

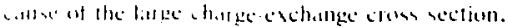

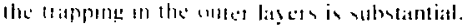

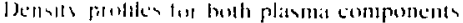

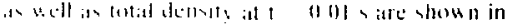

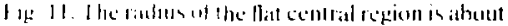

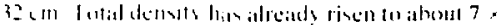
Ja' c in all the timle

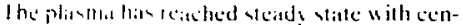

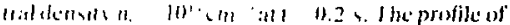
domily as ucll a the anmme for lbe 50)-keV beam is

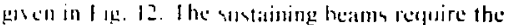

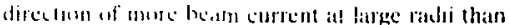
the statum hedlm besatuse of the lower trapping

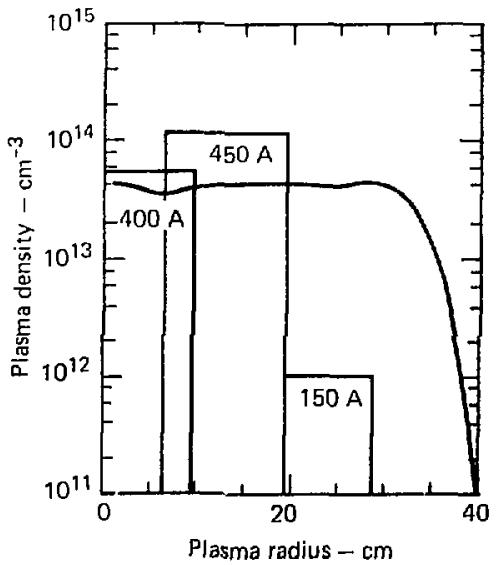

Fig. 10 Ikensity of $14-k(V$ plasuma component at $t=0,01$ s tugether with starlup-heam current dist ribution for MFTF rof. ercnce case (ere Table I),

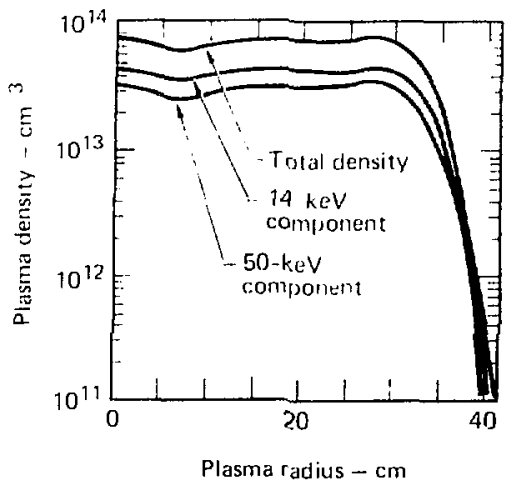

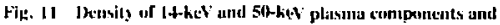

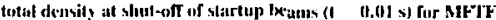
reftretter cisce.

cross setion. As mentioned earlior, the finer conIrol furnished by more beans would atlow a flatter profile to be attained. We sece that a stustainingbeim current of $750 \mathrm{~A} \mathrm{inc}$ vilent on the platsma is just adequate to achieve $\beta_{11}=0.5$ in at central region of radius $k_{k}=30 \mathrm{~cm}$ with a sharp fallof of density oulside this region. This is the calculation we used to normalize the anitytical results in Sec. 3.

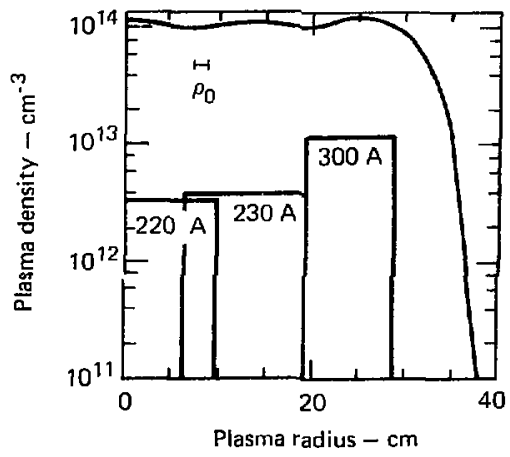

Fig. 12 Ptısmo density ut $t=0.2$ s with sustaining-tesam current distrihution for MFIF relerenec cuse. The l.armor radius $f_{1}$ at the plasma center is shon 11 . The plasmu contine. ment purameter no is $10^{12} \mathrm{~cm}^{3}, \mathrm{~s}$ for $\mathrm{r} \cdot 27$ cm and $3,10^{\prime}$ cm sor $\mathrm{c}>27 \mathrm{~cm}$. 


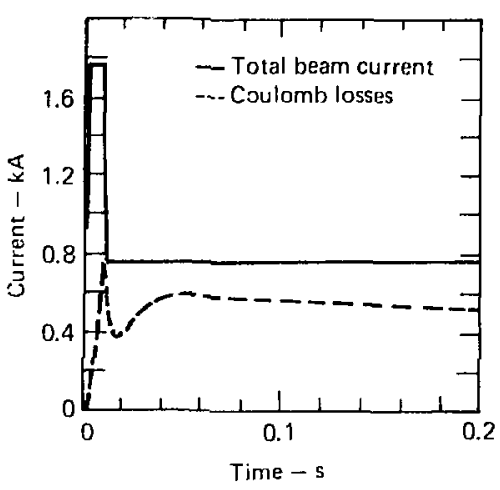

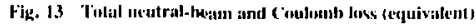
curremts wh time fitr Mrolf reference cule.

Severial additional yuantitien of inlerest for the refortrec tase ale shown in ligs. 13 ihrough 16. the totitl bean catrent tequivalent amperest an usll as the total losses die to coulomb scattering ale shoun in lig. 13 as a function ol tine. Bately visible neas 1 (o is the finite rise line of the beam current, laken as $1 \mathrm{~ms}$. Surface losses are given in Fig. 14. The slow rise in strface losses reflects the slow rise in molectular density outside the platsmat.

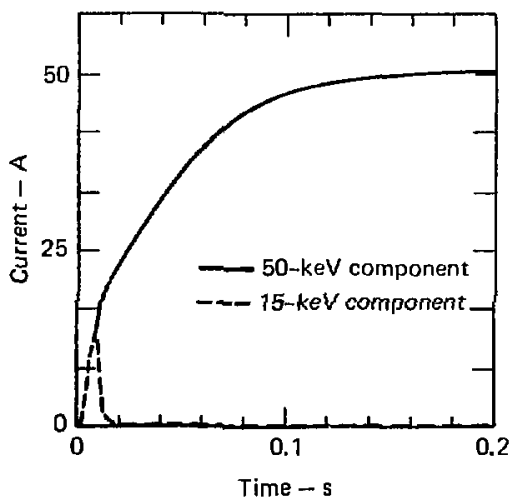

Fig. 14 Piusmu loss rate vitu charge exchange on reflux utsofr.; and molecules at surface (Lquivalent current) for MFTF refcrenrt cosie.

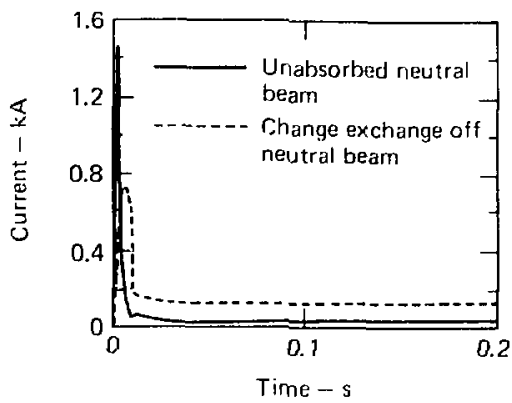

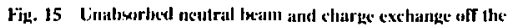
datural beam that feave the plisena (cyuivalent current) for MrTF reference case.

The total unabsorbed beam current as well an the charge-exchange current off the heam that leaves the plasma is shown in fig. 15. The unaburored beilm peaks at I ms. reflecting the linite rise time ol the injected heam. The chatrge exchange off the beam peaks at the later time, when the deinsty has built up enough Io cause appreciatble charge exchange off the plassmat.

The nel current to the plisma (i.e., the righthitnd side of $\mathrm{FG}, 12(0)$ integraled over the entire plasmal is shown w time in Fig. 16. An interesling feature is the net less of plitsmit that necurs jusl afler $0.01 \mathrm{~s}$. This loss in abstociated $\mathrm{w}$ ith the shulelf of the slattup beams. When buth slartup and stlse taining beams atre on. the plastara huilds up 10 at radius larger than can be supported by jual the 750-A sustaining beam current. When the vartup

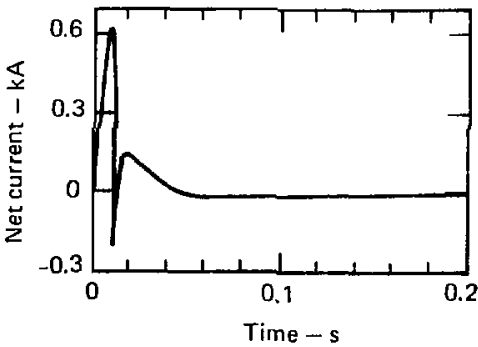

Fig. If Net rute of addition of ions to plasma for MFTF reference casc. 


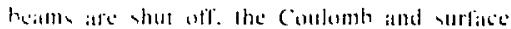
chatge enchange losses are greater than the beam

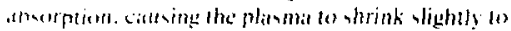
it ws that the sustaning heams can support

\section{liffects of Changes in n-}

If the plasmat condinement times do mor mest

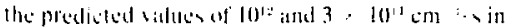

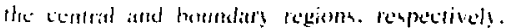
then the he:ant-cirrem requirements will be altered. Rithes thath itlempl fo find the sorrent requirsnuente moles dianged conditions. we hold the

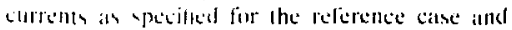
stuly the plathis properties when the continenent lime als sedeced.

The ereals-sile plasma-demsity profile lior a

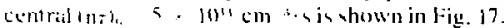

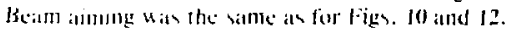
He nole a reduction in central dessity to aheut

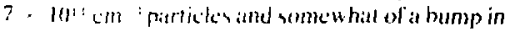
denhity neat the cige of the central region. but the

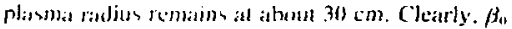

(1.5 could be attiancel at this lowered $n \pi$. hut only

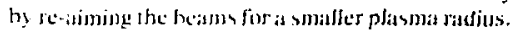
Sime ideal of the seiding of $r_{\text {, }}$ and $n$ with $n$ r can be ohianed by moling that most of the athorbed beam currem is lout in cosulumb scattering at stcady state (nec Fitg. 13). Ther. we have an approximate relattion fir the contrat region:

$n_{1} l_{1 i} \quad \frac{n \pi}{n \pi}$

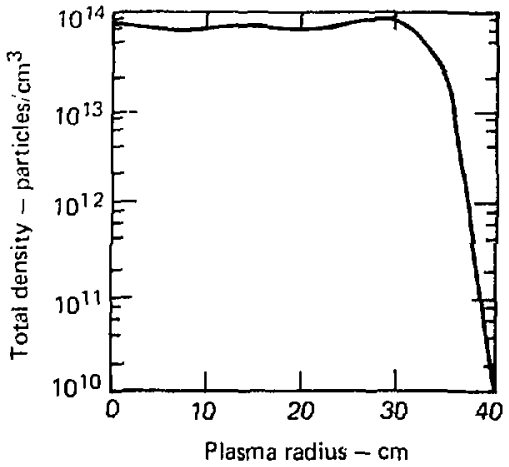

Figk 17 Siludy-sinte platmu-densily profile for (nt $\}_{j,}=5 \times 10^{\prime \prime}$ ajd $(n ;)_{6}, 3 \times 10^{\prime \prime} \mathrm{cm} \cdot \mathrm{s}$.
If the trapping efliciency its and ather paraneters remain fixed when $1 \mathrm{~s}$ is reduced. then

$n:(n+)):$

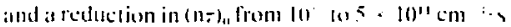

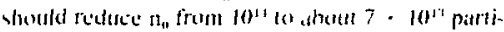
clevem : an it does. Inspection of the results shoses that $\eta_{1}$ also drops from $78^{\circ} ;$ to $67 \%$;

Amollec possihility is thill (11-), will nol he as large as prodicted by soaling from $2 X 11 B$ results. ligure is shows the steady-state plasma-density pritille for the same conditions as the referene cinc but with $\mid n \pi l_{1}$, seduced $101.1 \times 10^{11} \mathrm{~cm}^{3} \cdot \mathrm{s}$. The total hein current remuined the stame, but the beam earrent distribution was shifted somewhat, as shown in Fig. I8. to maintain a flat central density profile. We note that the plas na radius has shrunk from 30 to $2.5 \mathrm{~cm}$ as a result of the enhanced losses in the boundary layer. Thus. Not wouldobtain $R_{1} / \rho_{1}$

11 mather than 13 as desired. Such a decrease in $R_{w} / P_{a}$ would reduce $T_{*}$ in the interior and hence reduce inth.

\section{Effects of Changes in $I_{13}$}

Fach beim module is expected lo furnish abou 50-A equivalent current. Experience with the neutral-beam sources on 2 XIIB shows that on occasion a module fails to deliver current. We have bludied the effect of dropping out $50 \mathrm{~A}$ in each of

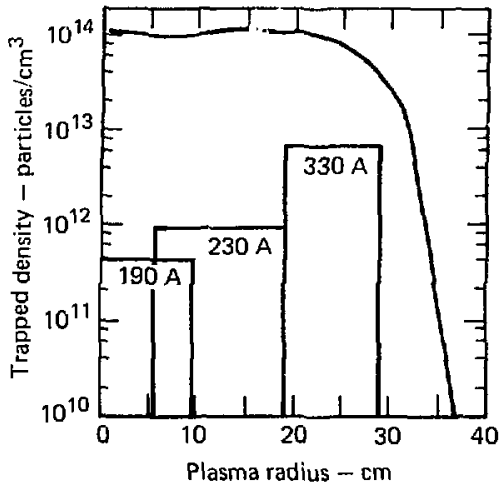

Fig. 18 Steudy-stute plasma-density profile for $(n-)_{0}-10^{12}$ and $(n r)_{1 \mathrm{k}}=1.1 \times 10^{11} \mathrm{~cm} " \mathrm{~s}$. Heam currents distrihuted as shith. 
the beams shown in Fig. 12. The largest effect occurs when the outermost beam is reduced. The resultant de.ssity profile for this latter case is shown in Fig. 19. We find only a slight shrinkage of the density profile over the reference case.

\section{Effects of Changes in Molecular Sources}

The reference citse has included estimates for the sources of molecular gas outside the plasma. It is desirable to study possible increases in two sources: wall reflux, and molecular gas streaming down the heam line from the neutral-beam source. In the former ease, we assume that good wall preparation yiclds a : ro reflux cuefficient of incident energetic attoms as morciules. We estimate the sicaming molecular eurrent at $8 \%$ of the neutralbeam current $I_{t}$. The effect on the steady-stute dersity of doubling the molectalar streim to $16 \%$ of $I_{13}$ is shown in Fig. 20. The added erosion of the surface has caused the plasmat radius to shrink by about $3 \mathrm{~cm}$. 'The molecular density surrounding the piasma has incriased from $2.4 \times 10^{\prime \prime}$ to $3.3 \times 10^{\prime \prime}$ particies - cor ".

To study the effeet of molecular reflux of charge-exchange atoms. we have arbitratily assumed that after $t=0.15 \mathrm{~s}$, all charge-exchange atoms reflux as molecules. Figure 21 shows the

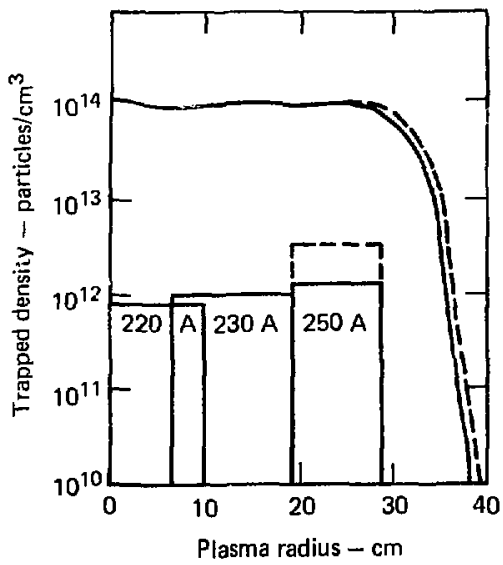

Fig. 19 Steady-state plasma-density profile when the oulermost beam from the cose of Fla. 12 is reduced by $50 \mathrm{~A}$. Figune 12 plesma-density profile shown deshed.

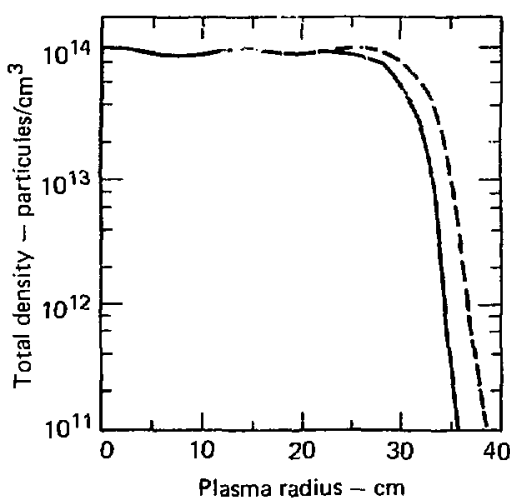

Fij, 2,l Sloady-state plusma-density profile for a molecular gas streant ticual to $16 \%$ of neutral-beam curront. Fipurc I2 plasma-density profile shown dashed.

erosion of the density profile to a steady-state value near $t=0.5 \mathrm{~s}$. Both of these results show that the plasma should be tolerant to a somewhat enhanced molecular density: that is. buildup to a steitly state is not prevented, but there is some reduction in plasma radius.

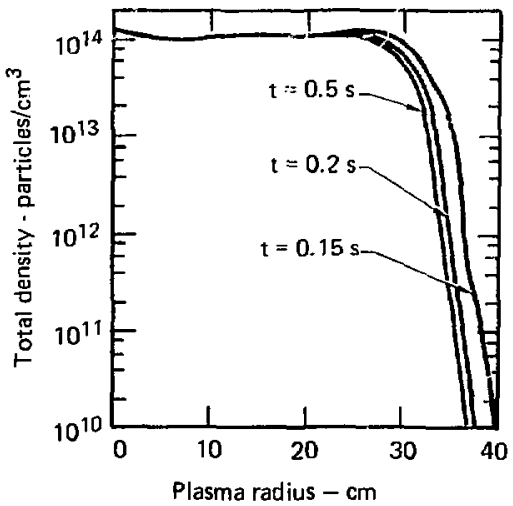

Fig. 21 Evolution of plasma-densily profile when all chargecxchange atoms are assumed to reflux as molecules after $\mathrm{I}=$ 0.15 s. Otherwise as Fig. 12. 


\section{Effects of Changes in $\overline{\mathbf{E}}_{\mathrm{i}}$}

The parametric variation discussed in Sec. 3 indicited that the required beam current should increase considerably if the mean plasma energy were reduced. We cin study this eflect also with the BUILDUP code, hut not in as much detail because of the number of icrations in beam aiming and current requijed to establish a flat density profile. We therefore choose to study one variation on the base case. at reduction in the mean ion energy from $50 \mathrm{keV}$ to $30 \mathrm{keV}$.

Maintenance of $\beta_{a}=0.5$ requires a density of $1.7 \times 10^{14}$ particles/cm ${ }^{3}$. The requirement $R_{1} / b_{01}=$ 13 allows a smaller radius, $R_{1} \approx 22 \mathrm{~cm}$. Re-itiming the heams to yield a fat density profile for a plasma of this radius, we find the density distribution shown in Fig. 22(a). The plasme radius is about $19 \mathrm{~cm}$ with a mean density of $.6 \times 10^{14}$ : hoth values are somewhit below the MFIF goals.

An increise in beam current to $1000 \mathrm{~A}$ yiefds the densi'y shown in Fig. 22(b). The radius and density have improved to $22 \mathrm{~cm}$ and $1.8 \times 10^{14}$ prarticles/cm ", respectively. We thus find agreement with the results of Sec. 3: increaned beam current is required if the mean energy is indeed less than the beam energy. as predicted by FokkerPlanck codes." .

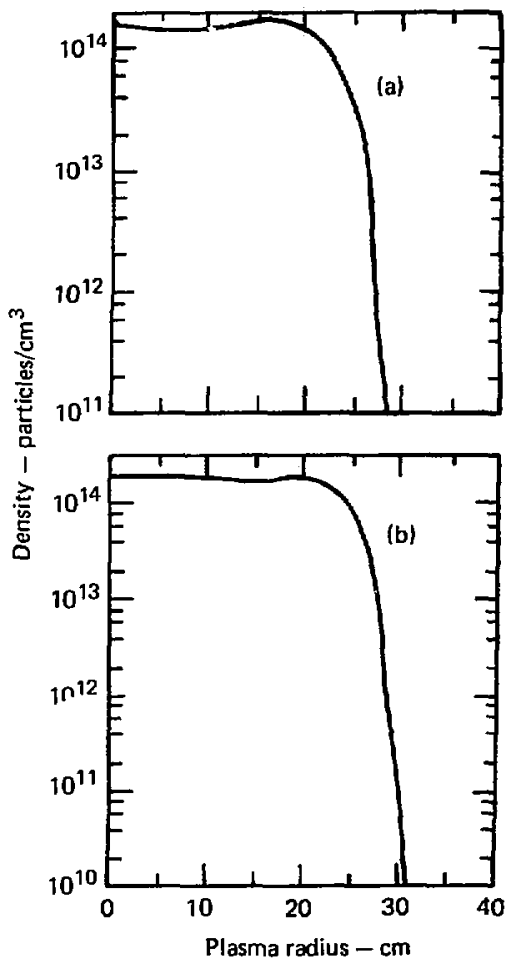

Fig. 22 Phame-density profiles for $\vec{E}_{1}=30 \mathrm{keV}$ and with heam giming to produce $R_{p}=22 \mathrm{~cm}$ : (a) ofher parumeters as in Tuble I, and (b) with sustalning-beam currert of $1000 \mathrm{~A}$. 


\section{NEUTRAI-BEAM CI RRENT REQUIREMENTS FOR FIELD-REVERSAL LXPERIMENTS}

In Sech. 3 and 4. we assumed that the MFIF plismat is a large-diameter $\beta$ - 0.5 plasma: this was the initial goal proposed in Rel. I. An alternative to this conventional mirror configuration is the fieldrevelsed geometry. "In indelition lo several studies of the possibility of achicving this geometry with neatral-heam injection, " i there have been experimental investigations in 2XIHB. "Since the advanlatges of the field-teversed geonetry are greall. we expect that the MFTF will be used for studies of the plisma buildus of field reversal. The persihility of these experiments has been reviewed." Subrequently, the physics requirements for field reversil hy boildup from neutral heams were more completely analyzed and reassessed.' In this section. we present some additional estimates ol the curren requirements for plasma buijdup to ficld ieversal.

In Ref. 7. the requirements for buildap wo field reversal were foumd ia be:

- The plasmit shoukd contain some highes attomit number (higher-Z) impurily, such ats $10 \%$ He* ar loc : and

- The minimum injeclion current is that resuired lo reach $3 B / B=1$ with open condinement, where the plasmat radius $R_{\text {, }}$ is

$$
R_{1}, l_{1} \quad 4 \text {, }
$$

where $\omega_{\text {in }}$ is the deuterium ion syroradius in vacuum.

The first requirement is necessary to produce an "Oklawa cument" neas the field null"; such impuritics can be added either from streamingplasma sources or from some of the neutral-beam modules. We shall now use the methods detveloped in Sec. 3 to estimate the injection eurrent needed to achieve the second requirement.

The scaled radius $R_{i} / p_{i}$ specified by $E_{q} .(22)$ is much smaller than that used in the previous sections of this report. Reducing the ratio $\mathrm{R}_{b} / \rho_{j}$ by direct reduction of the radius $R_{p}$ is limited by the divergence of the neutral-beam modules. Lowering $R_{b} / \rho_{\mathrm{i}}$ by increasing the average ion energy $\bar{E}_{1}$ would require much higher enelgy heams because of the square root dependence of $\rho_{1}$ on $\overrightarrow{\mathrm{E}}_{\mathrm{i}}$. Such neutral beams are not presently being planned for MFTF. although they have been discussed. ${ }^{k}$ 'The mignetic field $B$ is thus the most effective parameter for lowering the sealed ridius $\mathrm{R}_{1} / \mathrm{l}_{1}$ by rising the gyroradius $f_{1}$. Iherefore. we choose the low-field example (the 1.(17-'] ease of Ref. (1) as the starting poimt for the he buildup calculations.

The trapped current reguired 10 athieve $\triangle B / B$ 1 can be calculated using the lechniqulles Jeveloped in Siec. 3. For the ymall-dianeter plasmas. we assume that the plasma profile is Gaustian: hence, we was lig. flof to determine the reyuired wapped curen lor the longs, lhin model. Since $\mathrm{K}_{j+}$,

4 and 13 - 5.07 's, this plasma jo quile similir to the present 2 XJIB experiment, al is we sale the plasma parameters from those results. We cxpect the average ion energy to he n.at the hean energy. which (including both the stattup and the sustaining heams is approximately $35 \mathrm{keV}$. Thus, wh as infme I: $\quad 30 \mathrm{kcV}$ and $n \pi=2,10^{11} \mathrm{~cm}:$. ,. We use the same plasma length at in Reli. 6: $\mathrm{L}_{2}=50 \mathrm{~cm}$.

The lataped courent required is ploticd as a funclion of - $\beta$ - in lig. 23, where the effect of plasma pressure on $R_{1} / f_{1}$ is approxintiled using the long. Ihin model. In this casc, the field on the center is zero: i.c. $J B / B=1$ for $\beta_{11} \quad$ or $\beta \ldots .0 .42$. This requites a trapned eurent of only 450 A $B \mathrm{~B}$ eause the trapping efficiency for a beam aimed at the center with ithe plasmit is only 0.3 , we estimate a total bean current (assuming a $35 \%$ incrcase for surface charge-exchange losses) of appruximatcly $2000 \mathrm{~A}$. This is nearly the tolal current we expect to obtain with 24: sustaining and 24 statup source modules.

Because the plasmas deseribed here are actually rather short and tat, the long. thit model is a poor regresentation. Therefore, to null the fich on the axis we nust achieve $\beta_{1}-1$. Sirte this plasma is rather similar to the 2XIIB plasma. we expect $\beta_{0}=2$ for $\Delta B / B=1$. We obtain a lower linut for the required current hy neglecting the plasmi-pressure corrections for $R_{y} / p_{1}$, as suggested in Rel. 7. The trapped current required for no finite- $\beta$ correction is also shown in Fig. 23. For this case, $\langle\beta\rangle=0.86$. the laapped current required is $1051 A$, and the trapping effeiency is approximately 0.4 . Therefore, more than $2500 \mathrm{~A}$ is required. Thus, for both plasma models assumed here, at least 24 sustaining and 24 startup neutral-beam modules are required for experiments lo study the plasmat buildup to field reversal. 


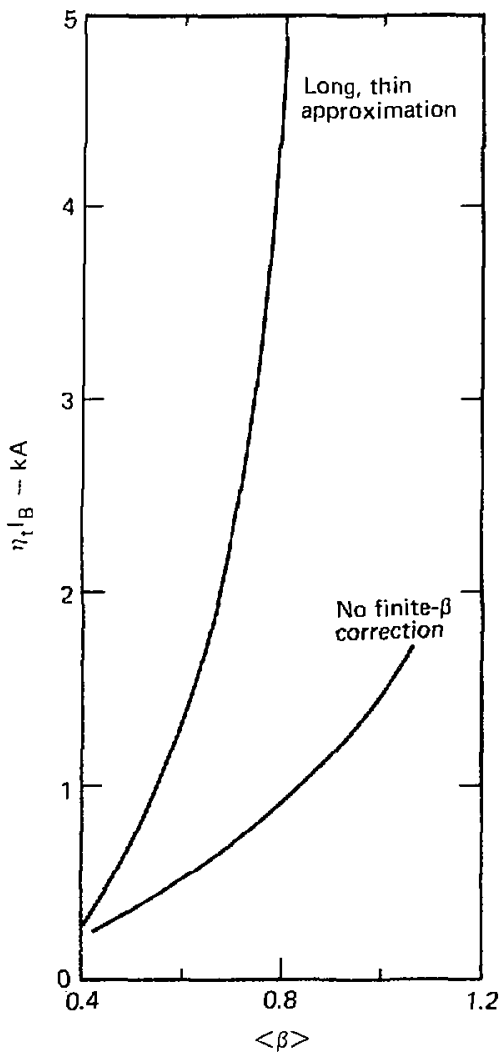

Fig. 23 The trapped current $\eta_{6} l_{11}$ reyuired for field-reversil studies as a function of averuge plasma beta $\langle\beta\rangle$, The cumdi. tion $\triangle H / B=1$ requires $<\beta>=0,43$ for $\theta$ long, thin plasma and $<\beta\rangle=0.86$ for a shorl plesma with no finite- $\beta$ correction. We usiume that the plasma density hes a Gaussian profile with $R_{1} / \mu_{\mathrm{i}}$ $=4$. 


\section{SUMMARY AND CONCLLSIONS}

Tal summariat. We bate reashessed the number of neut ral-heam power supplies reyuited to achicve the gorals of the MFIF. We began with an examilation af the beam line couptul curlem ex. pected from ceach medule and found that the molectulat mix of the present I,BS soutces will produce an outpul curren ol 5 I $\wedge$ with an average heam energy of sol keV. Inptovememe in source design be increste the aberage beam energy will leat lo at reduction in beam corrent snce the new|rializer efficiency decreanes an the energy in

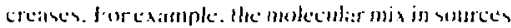
using the so-balled Mackengic hucked will produce a modele with an ondpus current of $37 \AA$ and an average ion cllsergy of fot keV. This rearese improvement will be repesed to athe ve the MFll gosal of an average ion energy of $50 \mathrm{keV}$.

The newtral beatul current requirements for at plasma with of o.s hate heen examined fis l wo different riadial plasslas profiles. Ihe first, a diffuse (Cianssian) profile. Was linmed turequire in excensol 50) sollece modules 10 sllstitin a large-diatmeter plasma. This latge current is required becallse the average betat is only lutir lenthe the peak beta for the assumed Gitussians profile. The cutrem reyuirements are surexhat more modest for a fat topped profile in which the ratio of the average beta to peatk bela is approxialately three-lourths. For this profile, unly 28 sumere modules are reyured to acthicve an average bela of 0.5 . The 24 modules specitied in Ref. I atre sullicient to achicve all average beta $-\beta$. 1).46. which is willsin $10 \%$ of the

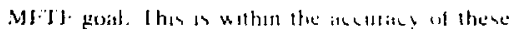
calculations.

(ialculatum of the avelate an enctes 1 . that

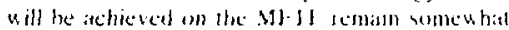
unceratin. Simple models that neglect the effect ot

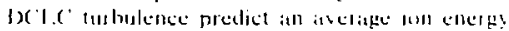
varging from $35 \mathrm{keV}$ (1) $45 \mathrm{kel}$, depending on the

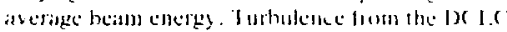
mode is expected to atse the enetge. Ihe Mlol t genal of t: 50 heV will be pousible only all sesureses in which the moleculis mis in ampoused

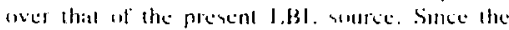
neulnalifer efficiensy in loutr, these sources will

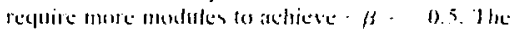

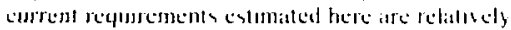

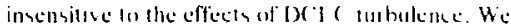
expect that this aldivils will bolh meteme the ate age ion ereergy and decreate the playma confine ment lime. lo first arder. lhese effect cancel, atmel

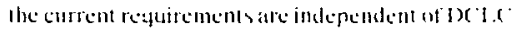
lutbulence.

Finally. we examined the current reyulrements for experiments to study pasmat buildup to fickd reversid. We feund that the combinitson of 24 sartup (20)-keV) and 24 astaming (80)-keV) molules is just afficient tu achiceve at planmat in which $J B / 13$ I. This is possibic al lou tields alt 1.07 Ti and small-ridius piamals $\left(R_{1}, m_{4} 4\right)$. Henee. we find that the cerrent requirements lior buth a katge-diameter. $\$ \quad 0.5$ plasmina and a fick!-

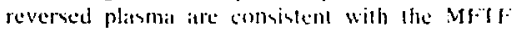
proposal." 


\section{REFERENCES}

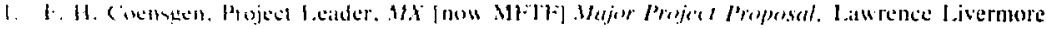

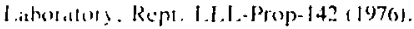

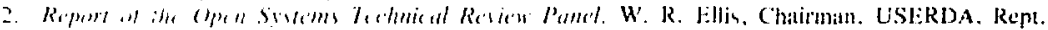
1.R1) 76140119061.

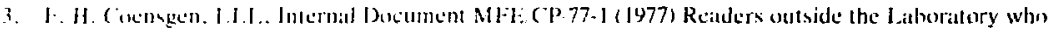

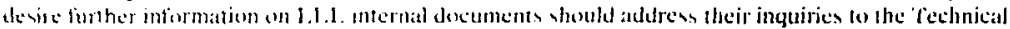
Informalion Department. Iassence livetmore laborators. I.ivernote. California 94550.

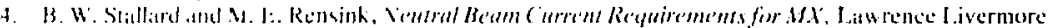
J atheritur). Reml. (CRL.-52305 (1977).

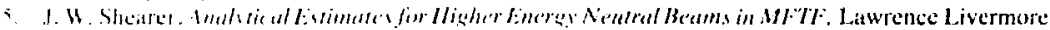
1.ahoratom! Repr. 1 (11)-17692 (1977).

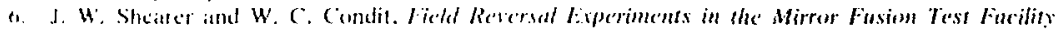

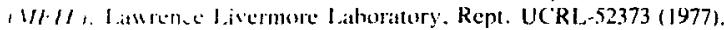

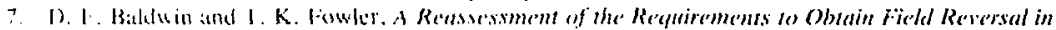

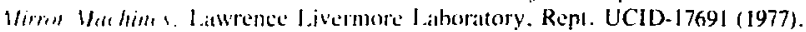

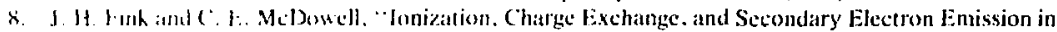

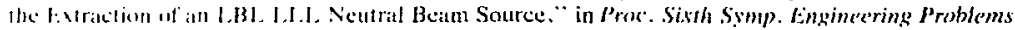

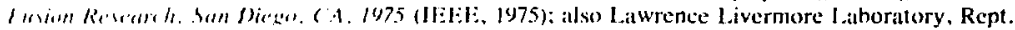
I' ( $R 1 .-77116$ (1975).

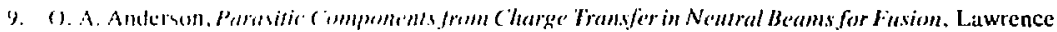
lincemefe lathuminy. Rept. U('ID)-1758) (1978).

11. k. H. Buthner. Latwence Berkedey Laboratory. privale communication (1978).

11. K. H. Burkncr, K. V. Pyle, and J. W. Stearns, “Intense, Mixed-Energy Hydrogen Beams for CTR Injection." Viul. Imsinn 15, 249 (19975).

12. ('. H. Barnell, J. A. Ray, E. Ricci, M. I. Wilker. E. W. McDanicl, E. W. Thomas, and H. B. Getbody,

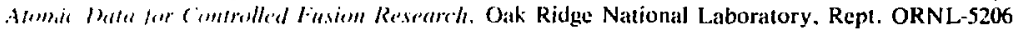
(1977).

13. I. Stewart. Princelon Plasma Physics Laboratory, private communication (1978).

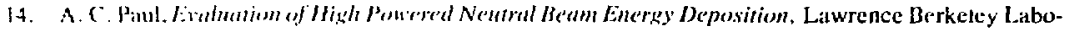
mitory. Rept. U(ID)-3827 (1976).

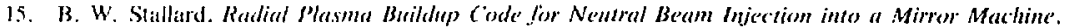
Lawrense liverinure Laburatory, Rept. UCRL-51784 (1976).

16. W. C. Condit, T'. K. Fowler. R. F. Post. Statws Report on Mirmor Alternatives, Lawrence Livermore Laborilory. Rept. UCR1-52008 (1976).

17. J. F. C'lauser, F. H. Coensgen, D. L. Correll, W. F. Cummins, R. P. Freis, R. K. Goodman, A. L. Hunt, T. B. Kaisdr. G. M. Melin, W. E. Nexsen, T. C. Simonen, B. W. Stallard, and W. C. Turner. Field

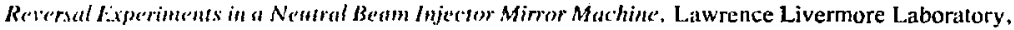
Rept. UCRI.-80857 (1978).

18. C. C. Damm, F. H. Cuensgen, R. S. Devoto, A. W. Molvik, G. D. Porter, J. W. Shearer, and B. W. Stallard. Dirretions for Pessible Upgrades of the Mirror Fusion Tesi Facility (MFTF). Lawrence Livermore 1.aboratory, Rept. UCRL-80475 (1977). 